\title{
Using airborne gamma-ray spectrometry and geochemistry to characterize the late Neoproterozoic ferroan magmatism in the Transversal subprovince of the Borborema Province, NE-Brazil
}

\author{
José Victor Antunes de Amorim* (D, Vanessa Biondo Ribeiro' (D, Ignez de Pinho Guimarães' (D), \\ Douglas José Silva Farias' (D, Jefferson Valdemiro de Lima' (D), Adejardo Francisco da Silva Filho' (D)
}

\begin{abstract}
Ferroan granites (585-530 Ma) in the Transversal subprovince of the Borborema Province (BP) comprise two groups: G1) slightly peraluminous to metaluminous, alkali-calcic rocks (Aroeiras Complex and Serra Branca - Coxixola dike swarms (SBCDS)); G2) metaluminous to slightly peraluminous, alkalic to alkali-calcic rocks (Queimadas and Prata intrusions). G1 are transitional from collision to transcurrence (ca. $585 \mathrm{Ma}$ ), or transcurrence to transtension (ca. $545 \mathrm{Ma}$ ). G2 represents the granitoids intruded during post-collisional crustal thinning (ca. $550 \mathrm{Ma}$ ), or coeval with deposition of intracratonic basins (ca. $530 \mathrm{Ma}$ ). The large-ion lithophile elements (LILE) and high field strength elements (HFSE) enriched geochemical signature of these granitoids are recognizable in gamma spectrometric maps of regional scale, highest values of $\mathrm{K}(\%), \mathrm{eTh}(\mathrm{ppm})$, and $\mathrm{eU}(\mathrm{ppm})$ contrast significantly with country rocks and magnesian granites. This study shows that gamma-ray spectrometric regional maps reflect the geochemical characteristics of the ferroan intrusions. Moreover, in the local maps for each intrusion, it is possible to identify internal heterogeneities in these plutons, which correlate to geological processes, geochemistry, and petrography. Diorites and gabbros show low to medium values of $\mathrm{K}(1-3 \%)$, eTh $(5-20 \mathrm{ppm})$ and eU $(0.2-2 \mathrm{ppm})$, contrasting with the high values of regions with a dominance of ferroan granitoids (K, 3-6\%; eTh, 15-60 ppm; eU, 2-4 ppm).
\end{abstract}

KEYWORDS: granitoids; ferroan; gamma-ray spectrometry; Borborema province; Geochemistry.

\section{INTRODUCTION}

Ferroan (A-type) granites have higher $\mathrm{Fe}^{\#}(\mathrm{FeOt} / \mathrm{FeO}+$ $\mathrm{MgO})$ ratios than cordilleran granites, and are rich in incompatible trace elements, as large-ion lithophile elements (LILE) and high field strength elements (HFSE). Nevertheless, they exhibit low contents of compatible trace elements in mafic silicates and feldspars (Loiselle and Wones 1979, Whalen et al. 1987, Eby 1992, Bonin 2007, Frost and Frost 2011). Hereof, airborne gamma-ray spectrometry constitutes an important tool for the identification of these intrusions, since it uses natural decay of U and Th (HSFE), and K (LILE) elements as parameters for differentiation of geological lithotypes.

Ferroan plutons of the Borborema Province (BP) are geochemically diverse, intrude in different geochronological intervals, mark shifts in the tectonic regime during some of the stages of the Brasiliano (= Pan-African) orogeny (Guimarães et al. 2004, 2005, Amorim et al. 2019, Dalan et al. 2019, Lages et al., 2016

${ }^{1}$ Universidade Federal de Pernambuco - Recife (PE), Brazil. E-mails: josevictor.amorim@ufpe.br, van.biondo@gmail.com, ignez@ufpe.br, douglasjsfarias@yahoo.com.br, jefferson1901@hotmail.com, afsf@ufpe.br

${ }^{*}$ Corresponding author. and Santos et al., 2014). Furthermore, they pre-date and occasionally occur close to mineralized granitic pegmatites and skarns (Baumgartner et al. 2006, Hollanda et al. 2010, 2017).

In the Transversal subprovince, the Aroeiras Complex is the oldest intrusion $(585 \pm 6 \mathrm{Ma}$ ). It marks the transition from the compressive stages, into the onset of the transcurrent event. The Queimadas Pluton $(550 \pm 6 \mathrm{Ma})$ is related to post-collisional and heterogeneous crustal thinning during the strike-slip event. The SBCDS and the Aroeiras Complex leucocratic late dikes mark the transition from strike-slip tectonics to uplift and transtension, around $545 \mathrm{Ma}$. The Prata Complex is the youngest intrusion (ca. $530 \mathrm{Ma}$ ), coeval with deposition of intracratonic sedimentary basins in a transtensional setting (Amorim et al. 2019).

Magmatic differentiation, tectonic environment and geochemical events (e.g., hydrothermal fluids action, chemical erosion, and metamorphism) can affect radioelements concentration and distribution observed for a specific intrusion, through the dissolution, increased mobility, or replacement of the elements. Thus, in any granitic suite, differences observed in geochemical patterns and their geological history have direct influence over their gamma-ray spectrometric signature.

Several authors used radioelements ratios to characterize granites suites around the world. For instance, Pagel (1982) reported $0.5 \%$ of $\mathrm{UO}_{2}$ in the Transversal part of the Vosges granites, in France, with a marked enrichment in the borders 
(up to $3.5 \%$ of $\mathrm{UO}_{2}$ ). Johan and Johan (1994) studied granites intrusions in Cinovec (Zinnwald), Czech Republic. In these granites, the zircon grains show magmatic zoning in both the hydrothermal dome and main granite body, and high contents of $\mathrm{H}_{2} \mathrm{O}$ (up to $18.5 \%$ in weight) and $\mathrm{F}$ (up to $2.41 \%$ ) partly replaced by monazite and xenotime. Broadly, hydration and fluoridation encourage the ingress of rare earth elements (REE), $\mathrm{U}$, and Th in zircon crystals by the substitution reaction (ETR, Y, $\mathrm{Sc})^{3+}+\mathrm{P}^{5+} \leftrightarrow \mathrm{Zr}^{4+}+\mathrm{Si}^{4+}$ (Johan and Johan 2005). According to Johan and Johan (2005), monazite crystals of Li-rich granites exhibit a positive correlation between Th content and $\mathrm{Ca}+\mathrm{Si}$, suggesting two types of substitution: $\mathrm{Th}^{4+}+\mathrm{Si}^{4+} \leftrightarrow(\mathrm{ETR})^{3+}$ $+\mathrm{P}^{5+}$ and $\mathrm{Ca}^{2+}+\mathrm{Th}^{4+} \leftrightarrow(\mathrm{ETR})^{3+}$. Allanite appears in several types of granites, especially in those metaluminous and peralkaline, either as a primary mineral with contents of $\mathrm{ThO}_{2}$ $(0.5-3 \%)$ higher than $\mathrm{UO}_{2}(0.3 \%)$ or as a secondary mineral phase (Pagel 1982, Bea 1996).

Uranium and Potassium become soluble in supergene conditions, unlike thorium, which has the lowest geochemical mobility of the three elements. This phenomenon is known as the antagonism between thorium and potassium described by Ostrovsky (1975). This geochemical behavior can be used not only to characterize differentiated granites intrusions (Ulbrich et al. 2009, Ribeiro et al. 2014) but also to identify possible new targets for exploration associated with hydrothermal processes (Ribeiro and Mantovani 2016).

In this paper, we focus on the study of the four distinct ferroan intrusions of the Transversal subprovince and identify their mutual gamma-ray spectrometric features and differences. The better knowledge of their radiometric signature will significantly contribute to the comprehension of the ferroan granites and their role in the $\mathrm{BP}$ geological evolution.

\section{REGIONAL GEOLOGY}

The BP (Fig. 1) (Almeida et al. 1981) comprises metasedimentary rocks and a Paleoproterozoic basement with complex tectonic history from Archaean until late Neoproterozoic, culminating in the assembly of western Gondwana, with the collision of major cratonic landmasses (São Franciso-Congo and São Luís-West Africa Cratons) along the Cryogenian-Ediacaran period (Van Schmus et al. 2008, references therein).

Van Schmus et al. (1995) used the Pernambuco and Patos E-W trending strike-slip shear zones (Fig. 2A) to divide the BP into three domains, subsequently renamed to subprovinces (Van Schmus et al. 2011). The Northern subprovince lies north of the Patos shear zone. The Transversal subprovince between the Pernambuco and Patos shear zone and the Southern subprovince stands between the Pernambuco shear zone and the São Francisco Craton.

Primarily, the Transversal subprovince comprises (Fig. 2B): Paeleoproterozoic basement orthogneisses $(2.5-2.0 \mathrm{Ga})$ with tonalite-trondhjemite-granodiorite (TTG) affinities, and small Archaean blocks (Santos 1995, Van Schmus et al. 1995, 2008, 2011, Neves et al. 2006, 2015, Santos et al. 2015, 2017); Mesoproterozoic (ca. $1.5 \mathrm{Ga}$ ) anorogenic orthogneisses and anorthosites (Sá et al. 2002, Accioly 2000); Tonian orthogneisses and supracrustal sequences of the Cariris Velhos event (Jardim de Sá et al. 1988, Brito Neves et al. 1995, 2001, Santos 1995, Kozuch 2003, Guimarães et al. 2012, 2016); Cryogenian to Ediacaran supracrustal sequences deposited before the main collisional event (Neves et al. 2006, Neves 2015); and EdiacaranCambrian plutons (Fig. 2B) (Almeida et al. 1967, Sial 1986, Brito Neves et al. 2003, Guimarães et al. 2004). During the late-Neoproterozoic, the whole Transversal subprovince was cut by strike-slip E-W trending dextral kinematic and NE-SW trending sinistral kinematic shear zones (Vauchez et al. 1995, Neves et al. 1996, 2000).

The Ediacaran-Cambrian magmatism in the Transversal subprovince has been the subject of extensive studies throughout the last decades (e.g., Almeida et al. 1967, Sial 1986, Brito Neves et al.2003, Guimarães et al. 2004, 2011, Sial and Ferreira 2016). Guimarães et al. (2004) used geochemical and geochronological data to categorize the granitoids from the Transversal subprovince within four groups:

- 640-600 Ma medium to high-K calc-alkaline granitoids;

- 590-581 Ma high-Kcalc-alkaline and shoshonitic granitoids;

- 570-550 Ma alkaline post-collision granites and ultrapotassic intrusions;

- 540-510 Ma A-type post-orogenic extension-related associated with subvolcanic bimodal magmatism.

Amorim et al. (2019) identified two geochemical groups of ferroan intrusions within the last three age intervals groups of Guimarães et al. (2004). The first group comprises slightly peraluminous to slightly metaluminous alkali-calcic granitoids; with low ${ }^{*} \mathrm{Fe}(\mathrm{FeOt} / \mathrm{FeOt}+\mathrm{MgO})$ biotite, which crystallized under intermediate $\mathrm{fO}_{2}$ conditions $(585 \mathrm{Ma}-$ Aroeiras Complex; $545 \mathrm{Ma}$ - SBCDS). The second group encompasses metaluminous to slightly peraluminous, alkalic to alkalic-calcic rocks, with high "Fe biotite and crystallized under low $\mathrm{fO}_{2}$ conditions ( $550 \mathrm{Ma}$ - Queimadas Pluton; ca. $530 \mathrm{Ma}$ - Prata Complex).

\section{GEOLOGICAL SETTING OF THE STUDIED FERROAN INTRUSIONS}

\section{Aroeiras Complex}

The Aroeiras Complex (Fig. 2B) intruded into an older Ediacaran pluton (Serra do Inácio Pereira), Cryogenian supracrustal sequences of the Surubim Complex, and Rhyacian orthogneisses and migmatites. The main granitic pluton intrudes ENE-WSW structural trending, suggesting that its emplacement during synchronous movements of E-W trending dextral Coxixola shear zone and NE-SW trending sinistral Batista shear zone. Granitic sheets and dioritic bodies, respectively related to mylonitic foliation and shear zone terminations, were subsequently cut by granitic dikes. The bimodal character of this intrusion is distinctive in extensional environments.

The Aroeiras Complex encompasses equigranular to porphyritic hornblende-biotite-monzogranite and 
biotite-syenogranite. Accessory phases are prismatic crystals of allanite and zircon, acicular apatite. The Aroeiras granitoids show typical textures of processes involving interactions between felsic and mafic magmas, and ilmenite crystals mantled by titanite suggesting later fluid percolation. Microgranular mafic enclaves (MME) are hornblende-biotite diorites or quartz diorites. Droplets of ovoid MME with crenulated borders, double enclave relations, granitic venules, and hybrid rocks with rapakivi texture are indicative of mingling and mixing processes that acted throughout the evolution of this intrusive complex.

\section{Queimadas Pluton}

The Queimadas Pluton (Fig. 2B) intruded Rhyacian gneisses. It has an E-W elongated $50 \mathrm{~km}^{2}$ body, showing $\mathrm{S}-\mathrm{C}$ dextral foliation with $\mathrm{C}$ foliation parallel to the $\mathrm{E}-\mathrm{W}$ trending of the Campina Grande Shear Zone. A late transcurrent dextral shear zone $60 \mathrm{Az}$ trending disrupts the body in a megaboudin-like shape (Almeida et al. 2002).

Petrographically, it comprises leucocratic (less than $10 \%$ of mafic phases) porphyritic biotite-amphibole granodiorites to monzogranites. Accessory phases comprise euhedral crystals of allanite, apatite, prismatic or rounded crystals of zircon,



Br/PA: Brasiliano/Pan-African Belts; PaleoPr: Paleoproterozoic crust. Subprovinces and domains - NSP: Northern subprovince; TSP: Transversal subprovince; SSP: Southern subprovince; PEAL: Pernambuco-Alagoas domain; SD: Sergipano domain; MK: Mayo Kebi terrane; NWCD: NW Cameroon domain; AYD: AdamawaYadé domain; YD: Yaoundé domain; OU: Oubanguides fold belt. Shear zones and faults - PaSZ: Patos shear zone; PeSZ: Pernambuco SZ; TBL: Transbrasiliano Lineament; TBF: Tcholliré-Banyo fault; AF: Adamawa fault. Cities - N: Natal; R: Recife; S: Salvador; D: Douala; G: Garoua; K: Kaduna area of Nigeria.

Figure 1. Sketch map of a part of west Gondwana, in pre-drift reconstructions, modified from Van Schmus et al. (2008). 
subhedral crystals of ilmenite hosted by biotite or amphibole, and rare monazite crystals. Quartz-monzonitic and quartz-dioritic bodies occur close to the contact with country rocks, and microgranular mafic enclaves are locally observed in the porphyritic monzogranites and granodiorites (Almeida et al.2002).

Brittle-ductile conditions deformed the Queimadas Pluton during the ductile to brittle transition stage of the Brasiliano/ Pan-African Event (Almeida et al. 2002). Quartz ribbons, mosaic texture, and kinks of biotite represent textural aspects of ductile deformation, disrupted sigmoidal porphyroclasts of plagioclase with patchy extinction, while necking, disruption and boudin-like shape of the Queimadas Pluton are the results of the brittle system.

\section{Serra Branca - Coxixola dike swarms}

The SBCDS intruded into Paleoproterozoic orthogneisses, Neoproterozoic supracrustal sequences, and magnesian alkali-calcic Ediacaran plutons of the Transversal subprovince (Fig. 2B). The main NE-SW trending dike population crosscuts the flat-lying foliation of supracrustal sequences, as well as basement rocks. Closer to the dextral E-W trending Coxixola shear zone, dikes intruded concordant with the steeply-dipping mylonitic foliation, with no signs of deformation, suggesting that the intrusion succeeded the transcurrent stage.

The dike sets contain a monotonous mineral assemblage, constituted by porphyritic hornblende-biotite granite and equigranular biotite granite. However, accessory mineral phases are abundant in the hornblende-biotite granites, comprising prismatic crystals of zircon, allanite and subhedral crystals of ilmenite.

\section{Prata Complex}

The Prata Complex (Fig. 2B) intruded Siderian to Rhyacian orthogneisses and migmatites. It comprises several granitic intrusions, as dikes and elongated stocks (Melo 1997, Guimarães et al. 2005, Hollanda et al. 2010). Swarms of MME occur near the eastern boundary of the Complex and follow an NNE and E-W trending of diabase dikes. Solid-state deformation is rare and restricted to the western boundary of the Prata Complex, where it is in contact with the Prata Shear Zone.

Biotite-syenogranite and hornblende-biotite monzogranites are the main facies of the Prata Complex. Additionally, intermediate to mafic rocks, such as monzodiorite to quartz monzonite, diorite and norite, occur as MME. Enclave swarms of norite separate the Prata Complex into two main granitic plutons (Guimarães et al. 2005). The southern intrusion (Santa Catarina Pluton - Hollanda et al. 2010) comprises biotite syenogranites, whereas the northern (Sumé Pluton - Hollanda et al. 2010) comprises hornblende-biotite monzogranites (Melo 1997, Hollanda et al. 2010). The main accessory phases are allanite rimmed by epidote, titanite, apatite, and zircon. Several MME and syn-plutonic dikes observed in the SE limit of the Sumé Pluton display crenulated contacts and ovoid feldspar crystals mantled by plagioclase (rapakivi texture). Such characteristics are indicative of mingling and mixing processes between granitic and dioritic magmas (Melo 1997, Guimarães et al. 2005).

A
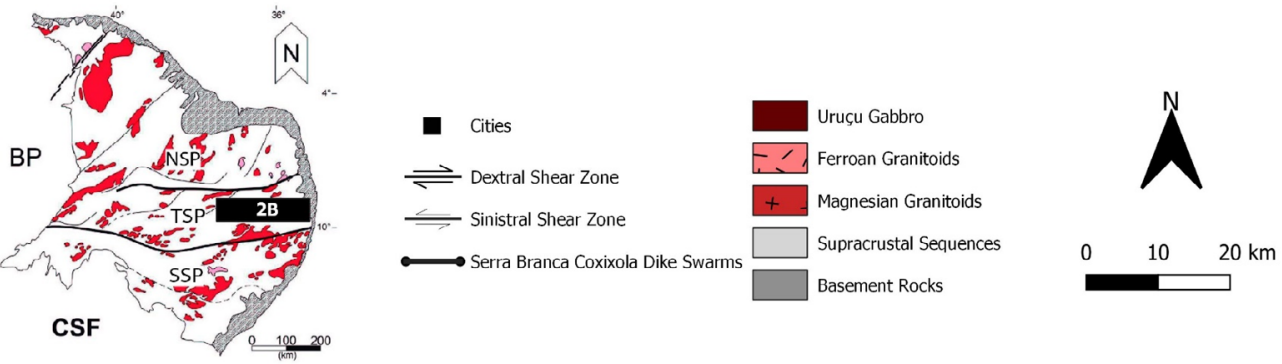

$37^{\circ} 0^{\prime} \mathrm{W}$

$36^{\circ} 0^{\prime} \mathrm{W}$

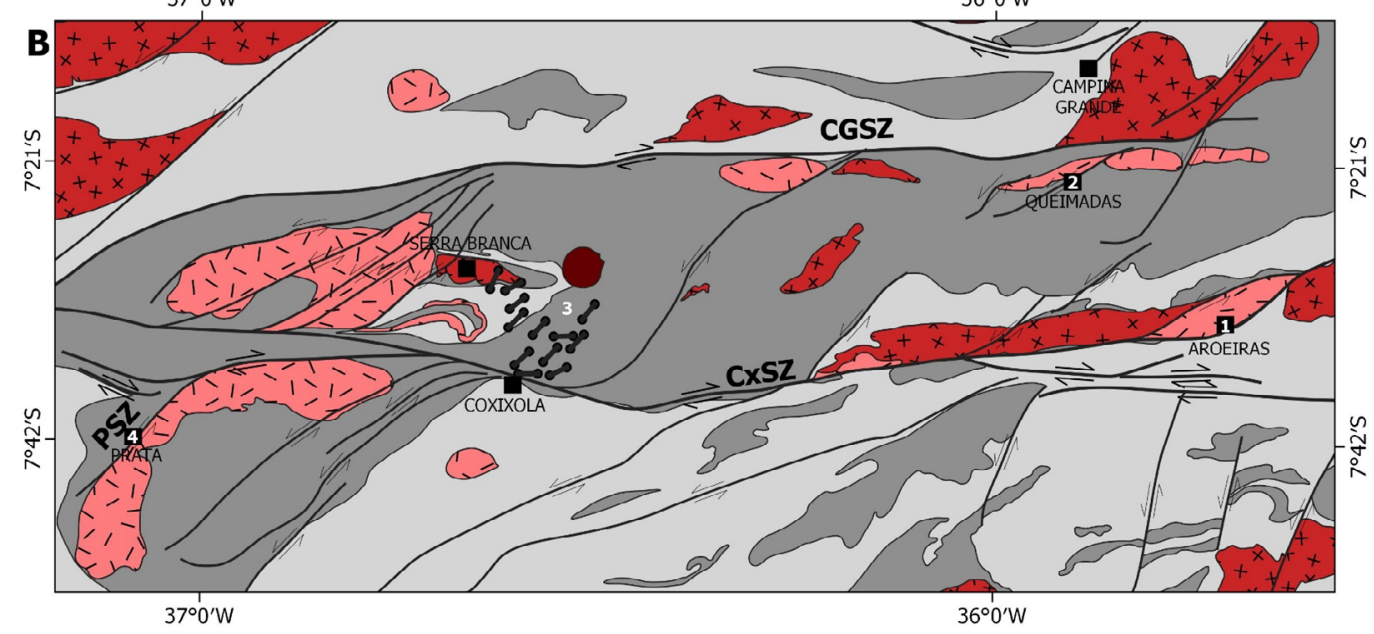

NSP: Northern subprovince; TSP: Transversal subprovince; SSP: Southern Subprovince; BP: Parnaíba Basin; CSF: São Francisco Craton; PSZ: Prata shear zone; CGSZ: Campina Grande shear zone; CxSZ: Coxixola shear Zone; Intrusions - 1: Aroeiras Complex; 2: Queimadas Pluton; 3: Serra Branca-Coxixola dike swarms area; 4: Prata Complex.

Figure 2. (A) Sketch map of brasiliano intrusions of the Borborema Province. (B) Simplified map with the studied intrusions and associated shear zones. 
ANALYTICAL METHODS

\section{Whole-rock geochemistry}

A total of 18 geochemical analyses were performed in the Aroeiras Complex and the SBCDS. Major elements concentration were obtained by $\mathrm{LiBO}_{2}$ fusion inductively coupled plasma emission spectrometry (ICP-AES), whilst trace elements concentrations were determined by $\mathrm{LiBO}_{2}$ fusion inductively coupled plasma mass spectrometry (ICP-MS) at Acme Laboratories Canada. Representative analyses are presented in Table 1.

Whole-rock compositions of the Queimadas Pluton and Prata Complex included in this work have been collected from the literature. In addition, trace element data have been recalculated to reasonable comparison (Almeida et al. 2002, Melo 1997, Guimarães et al. 2005).

\section{Geophysical data}

Airborne gamma-ray data were acquired from two surveying projects of the CPRM (Brazilian Geological
Survey) (CPRM 2008, 2010). Acquisition parameters were nearly the same for both surveys, as presented in Table 2. Gamma-ray spectrometers used were the EXPLORANIUM model GR-820, and the Radiation Solutions Inc. model RS-500.

Table 2. Technical specifications of each airborne survey.

\begin{tabular}{lcc}
\hline Project & $\begin{array}{c}\text { Borda Leste } \\
\text { do Planalto da } \\
\text { Borborema }\end{array}$ & $\begin{array}{c}\text { Pernambuco- } \\
\text { Paraíba }\end{array}$ \\
\hline Year & $2007-2008$ & 2009 \\
Flight line spacing & $500 \mathrm{~m}$ & $500 \mathrm{~m}$ \\
Flight nominal height & $100 \mathrm{~m}$ & $100 \mathrm{~m}$ \\
Flight line direction & $\mathrm{N}-\mathrm{S}$ & $\mathrm{N}-\mathrm{S}$ \\
Control line direction & $\mathrm{E}-\mathrm{W}$ & $\mathrm{E}-\mathrm{W}$ \\
Control line spacing & $10 \mathrm{~km}$ & $10 \mathrm{~km}$ \\
Sampling time & $1.0 \mathrm{~s}$ & $1.0 \mathrm{~s}$ \\
\hline
\end{tabular}

Source: CPRM 2008, 2010.

Table 1. Major and trace element data for representative samples of the Aroeiras Complex and Serra Branca - Coxixola dike swarm.

\begin{tabular}{|c|c|c|c|c|c|c|c|c|c|c|c|c|c|c|c|c|c|c|c|}
\hline Sample & $\begin{array}{l}\text { ARO- } \\
\text { O1A }\end{array}$ & $\begin{array}{c}\text { ARO- } \\
\text { 05A }\end{array}$ & $\begin{array}{l}\text { ARO- } \\
\text { 43A }\end{array}$ & $\begin{array}{l}\text { ARO- } \\
\text { 43B }\end{array}$ & $\begin{array}{c}\text { ARO- } \\
45\end{array}$ & $\begin{array}{c}\text { ARO- } \\
46\end{array}$ & $\begin{array}{l}\text { ARO- } \\
75\end{array}$ & $\begin{array}{c}\text { ARO- } \\
100\end{array}$ & $\begin{array}{l}\text { ARO- } \\
\text { 101B }\end{array}$ & $\begin{array}{l}\text { ARO- } \\
\text { 101C }\end{array}$ & $\begin{array}{l}\text { ARO- } \\
\text { 101D }\end{array}$ & $\begin{array}{l}\text { ARO- } \\
\text { 102A }\end{array}$ & $\begin{array}{l}\text { ARO- } \\
\text { 102B }\end{array}$ & $\begin{array}{c}\text { ARO- } \\
104\end{array}$ & $\begin{array}{l}\text { MA- } \\
03\end{array}$ & $\begin{array}{l}\text { MA- } \\
\text { 10A }\end{array}$ & $\begin{array}{c}\text { MA- } \\
11\end{array}$ & $\begin{array}{l}\text { MA- } \\
18\end{array}$ & $\begin{array}{c}\text { MA- } \\
\text { 50 }\end{array}$ \\
\hline $\mathrm{SiO}_{2}$ & 72.51 & 69.88 & 52.44 & 70.92 & 71.14 & 51.31 & 70.3 & 66.38 & 65.62 & 67.59 & 53 & 52.93 & 66.56 & 65.49 & 72.74 & 72.64 & 73.24 & 72.96 & 71.77 \\
\hline $\mathrm{TiO}_{2}$ & 0.18 & 0.367 & 2.03 & 0.28 & 0.32 & 2.22 & 0.29 & 0.54 & 0.67 & 0.52 & 1.77 & 2.5 & 0.52 & 0.58 & 0.23 & 0.2 & 0.19 & 0.28 & 0.22 \\
\hline $\mathrm{Al}_{2} \mathrm{O}_{3}$ & 14.18 & 14.35 & 14.65 & 14.41 & 13.92 & 14.5 & 14.43 & 15.83 & 15.41 & 14.71 & 14.9 & 14.29 & 14.92 & 14.84 & 13.95 & 13.77 & 13.76 & 13.86 & 13.88 \\
\hline $\mathrm{Fe}_{2} \mathrm{O}_{3}$ & 1.98 & 3.61 & 14.33 & 2.49 & 2.94 & 14.63 & 3.08 & 4.35 & 5.11 & 4.47 & 13.75 & 12.96 & 4.96 & 5.74 & 1.86 & 1.91 & 1.5 & 2.11 & 2.32 \\
\hline $\mathrm{MnO}$ & 0.04 & 0.053 & 0.19 & 0.05 & 0.05 & 0.21 & 0.06 & 0.06 & 0.06 & 0.05 & 0.19 & 0.18 & 0.07 & 0.09 & 0.02 & 0.03 & 0.02 & 0.03 & 0.03 \\
\hline $\mathrm{MgO}$ & 0.28 & 0.49 & 1.84 & 0.34 & 0.43 & 2.47 & 0.35 & 0.86 & 0.9 & 0.73 & 1.86 & 2.7 & 0.73 & 0.75 & 0.29 & 0.24 & 0.24 & 0.25 & 0.21 \\
\hline $\mathrm{CaO}$ & 1.57 & 1.93 & 4.77 & 1.42 & 1.61 & 5.15 & 1.38 & 2.78 & 2.5 & 2.33 & 4.72 & 5.39 & 2.47 & 2.56 & 1.03 & 1.1 & 0.94 & 1.05 & 1.19 \\
\hline $\mathrm{Na}_{2} \mathrm{O}$ & 3.37 & 3.61 & 3.86 & 3.55 & 3.46 & 3.81 & 3.99 & 3.42 & 3.89 & 3.36 & 3.66 & 3.5 & 3.61 & 3.51 & 2.97 & 2.98 & 2.93 & 3.07 & 3.19 \\
\hline $\mathrm{K}_{2} \mathrm{O}$ & 5.22 & 4.77 & 3.85 & 5.5 & 4.91 & 3.14 & 4.96 & 4.22 & 4.09 & 4.59 & 3.62 & 2.97 & 4.38 & 4.61 & 5.87 & 5.91 & 5.82 & 5.63 & 5.86 \\
\hline $\mathrm{P}_{2} \mathrm{O}_{5}$ & 0.03 & 0.128 & 1.22 & 0.06 & 0.08 & 1.57 & 0.15 & 0.16 & 0.23 & 0.18 & 1.17 & 1.16 & 0.19 & 0.25 & 0.05 & 0.05 & 0.05 & 0.05 & 0.06 \\
\hline LOI & & & & & 0.8 & & 0.7 & 0.8 & 1 & 0.9 & 0.8 & 0.9 & 1 & 1.1 & & & & & \\
\hline Total & 99.36 & 99.188 & 99.18 & 99.02 & 99.66 & 99.01 & 99.69 & 99.4 & 99.48 & 99.43 & 99.44 & 99.48 & 99.41 & 99.52 & 99.01 & 98.83 & 98.69 & 99.29 & 98.73 \\
\hline \multicolumn{20}{|c|}{ Trace-element compositions (ppm) } \\
\hline $\mathrm{Ba}$ & 1,540 & $1,572.6$ & $1,901.2$ & 1,701 & 1,326 & 1,564 & 1,342 & 2,660 & 2,021 & 2,079 & 2,187 & 1,530 & 2,318 & 2,225 & 851 & 662 & 730 & 667 & 620 \\
\hline $\mathrm{Sr}$ & 255.2 & 267.9 & 415.2 & 219.2 & 180 & 432.5 & 169.1 & 348.6 & 272 & 255.2 & $4,19.3$ & 446.4 & 241.2 & 251.7 & 182.7 & 142.9 & 154 & 104.8 & 99.5 \\
\hline $\mathrm{Rb}$ & 95 & 101 & 56.1 & 95 & 116.2 & 60.4 & 129.7 & 96.1 & 103.9 & 100.1 & 56.2 & 63.2 & 89.7 & 91.6 & 219.5 & 204.1 & 228 & 267.7 & 237.2 \\
\hline Th & 12.2 & 13.4 & 6.3 & 17.7 & 17.8 & 6.1 & 21.4 & 19.2 & 18.4 & 22.7 & 7 & 6.1 & 20.1 & 16.7 & 32.8 & 43.6 & 43.4 & 63 & 39.9 \\
\hline $\mathrm{Ni}$ & 2.2 & 2.6 & 4.7 & 3.8 & 4.1 & 8.6 & 3 & 6.7 & 5.9 & 3.2 & 4.1 & 12.2 & 6.2 & 5.9 & $<20$ & $<20$ & $<20$ & $<20$ & $<20$ \\
\hline $\mathrm{Y}$ & 36.5 & 38.8 & 78.7 & 25.8 & 25 & 63.7 & 34.3 & 35 & 37.1 & 40.1 & 76.9 & 59.9 & 48 & 43.4 & 13.4 & 14.7 & 15.6 & 22.7 & 12.2 \\
\hline $\mathrm{Nb}$ & 18.8 & 19.8 & 41.1 & 16 & 19.4 & 39.9 & 31.4 & 19.9 & 24.9 & 26.2 & 41.1 & 37 & 29.9 & 29.2 & 14.6 & 17.3 & 16.9 & 24.3 & 19.1 \\
\hline $\mathrm{Zr}$ & 201.3 & 201 & 903 & 291 & 285.7 & 640.9 & 324.2 & 453.3 & 463.3 & 501.5 & 801.8 & 654.4 & 549.8 & 595.5 & 219.8 & 190.4 & 183.1 & 266.5 & 236.9 \\
\hline $\mathrm{Hf}$ & 5.8 & 5.8 & 18.1 & 7.7 & 8.1 & 14.6 & 8 & 11.5 & 11.1 & 11.6 & 16.8 & 14.3 & 12.9 & 13.8 & 6.5 & 6.4 & 5.1 & 7.6 & 7.2 \\
\hline $\mathrm{Ta}$ & 1 & 1 & 2.1 & 0.8 & 0.8 & 2.4 & 1.6 & 0.7 & 0.9 & 1.1 & 2.2 & 2.1 & 1.7 & 1.1 & 0.7 & 0.8 & 1.2 & 1 & 0.8 \\
\hline $\mathrm{La}$ & 55.2 & 72.5 & 87.9 & 84.8 & 87.1 & 92 & 85.2 & 134.8 & 131.2 & 139.8 & 110 & 87.5 & 128.1 & 112.5 & 97.4 & 103.5 & 94 & 157.7 & 141.7 \\
\hline $\mathrm{Ce}$ & 109.9 & 129.7 & 181.8 & 152.7 & 163.9 & 190.5 & 157.2 & 241.2 & 237.7 & 267.7 & 224.1 & 182.4 & 240.3 & 216.2 & 173.9 & 188.2 & 161.1 & 273.9 & 275.0 \\
\hline $\mathrm{Nd}$ & 40.4 & 53.38 & 94.1 & 57 & 56.6 & 89.6 & 51.7 & 86.6 & 87 & 98.4 & 103.3 & 84.3 & 87.5 & 83.9 & 58.2 & 64.1 & 52.7 & 87.4 & 81.8 \\
\hline $\mathrm{Sm}$ & 8 & 8.5 & 16.6 & 9.05 & 8.83 & 16.71 & 9.05 & 12.87 & 13.25 & 14.72 & 19.14 & 15.58 & 13.83 & 13.86 & 8.09 & 9.56 & 7.55 & 12.84 & 11.02 \\
\hline $\mathrm{Eu}$ & 1.62 & 1.68 & 4.38 & 1.73 & 1.36 & 4.3 & 1.21 & 2.16 & 2.14 & 2.11 & 4.86 & 3.97 & 2.25 & 2.33 & 0.72 & 0.61 & 0.61 & 0.79 & 0.81 \\
\hline $\mathrm{Gd}$ & 6.86 & 7.4 & 15.65 & 6.7 & 6.68 & 15.23 & 7.61 & 9.88 & 10.91 & 11.6 & 17.6 & 14.23 & 11.09 & 11.46 & 5.28 & 6.52 & 5.49 & 8.86 & 7.14 \\
\hline $\mathrm{Tb}$ & 1.16 & 1.2 & 2.55 & 1.02 & 1.06 & 2.45 & 1.27 & 1.26 & 1.34 & 1.5 & 2.46 & 1.96 & 1.47 & 1.53 & 0.58 & 0.73 & 0.69 & 1.01 & 0.68 \\
\hline Dy & 6.55 & 6.65 & 13.79 & 4.73 & 5.26 & 12.58 & 6.21 & 7.21 & 7.66 & 8.65 & 14.23 & 11.71 & 8.9 & 8.73 & 2.95 & 3.3 & 3.42 & 4.84 & 2.84 \\
\hline $\mathrm{Er}$ & 3.58 & 3.54 & 7.41 & 2.69 & 2.74 & 7.62 & 3.95 & 3.33 & 3.56 & 4.22 & 7.62 & 5.89 & 4.78 & 4.31 & 1.22 & 1.42 & 1.4 & 1.98 & 1.01 \\
\hline $\mathrm{Yb}$ & 3.43 & 3.74 & 6.7 & 2.57 & 2.42 & 6.59 & 3.55 & 2.9 & 3.5 & 3.74 & 7.44 & 5.42 & 4.49 & 4.05 & 1.18 & 1.29 & 1.34 & 1.65 & 0.67 \\
\hline $\mathrm{Lu}$ & 0.5 & 0.51 & 0.98 & 0.39 & 0.36 & 1.02 & 0.53 & 0.46 & 0.48 & 0.53 & 1.08 & 0.83 & 0.69 & 0.59 & 0.18 & 0.21 & 0.21 & 0.25 & 0.11 \\
\hline
\end{tabular}

ARO: Aroeiras granitoids and diorites; MA: SBCDS granitoids. 
Gamma spectrometric data was collected considering, simultaneously, four energetic intervals. Since ${ }^{238} \mathrm{U}$ and ${ }^{232} \mathrm{Th}$ do not emit gamma radiation, the products of their decay are used for gamma-ray quantification: ${ }^{214} \mathrm{Bi}$ and ${ }^{208} \mathrm{Tl}$, respectively. The energy windows for each element were: ${ }^{40} \mathrm{~K}(1.37$ $1.57 \mathrm{MeV})$, eTh $(1.66-1.86 \mathrm{MeV})$, eU $(2.41-2.81 \mathrm{MeV})$ and total count $(0.41-2.81 \mathrm{MeV})$. The Brazilian Geological Survey has done the airborne gamma-spectrometric data processing and respected recommendations of IAEA (1991). Available data had corrected the Compton effect, flight effective height, cosmic background removal from the airplane, atmospheric Radon and altimetric correction. Parallax effect was not identified, and no correction was necessary.

\section{RESULTS AND DISCUSSION}

\section{Geochemistry of the ferroan intrusions}

Granitoids are ferroan, $\mathrm{Fe}^{*}(\mathrm{FeOt} / \mathrm{MgO}+\mathrm{FeOt})>0.81$; metaluminous to peraluminous, alumina saturation index (ASI) ranging from 0.93 to 1.06; displaying alkali-calcic to a slightly alkalic character with the modified alkali-lime index (MALI) ranging from 4.86 to 8.8. The Aroeiras Complex diorites are ferroan $\left(\mathrm{Fe}^{*}>0.81\right)$; metaluminous, with ASI values between 0.79 and 0.87 ; and alkalic with MALI values ranging from 1.08 to 2.94 (Fig. 3).

The chondrite-normalized (Nakamura 1974) REE patterns (Fig. 4) of the Aroeiras Complex granites are fractionated, with $(\mathrm{Ce} / \mathrm{Yb})_{\mathrm{N}}$ ratios ranging from 8.15 to 21.15 , and exhibit negative Eu anomalies $\left(\mathrm{Eu} / \mathrm{Eu}^{*}=0.45\right.$ to 0.68$)$. The granitoids of the Queimadas Pluton display negative Eu anomalies with (Ce/ $\mathrm{Yb})_{\mathrm{N}}$ ratios varying from 10.14 to 17.47 . The Serra Branca Coxixola samples exhibit significant negative $\mathrm{Eu}$ anomalies $\left(\mathrm{Eu} / \mathrm{Eu}^{*}=0.23\right.$ to 0.34$)$ and $(\mathrm{Ce} / \mathrm{Yb})_{\mathrm{N}}$ ratios ranging from 30.58 to 104.39 . The REE patterns of granitoids from the Prata Complex rocks are fractionated, with $(\mathrm{Ce} / \mathrm{Yb})_{\mathrm{N}}$ ratios between 6.8 and 19.76, and characterized by negative $\mathrm{Eu}$ anomalies $\left(\mathrm{Eu} / \mathrm{Eu}^{*}=0.21-0.65\right)$.

The incompatible element patterns (Fig. 5) of the studied granitoids normalized to the values suggested by Sun and McDonough (1989) show peaks in Th and $U$, variable troughs at $\mathrm{Nb}$ and $\mathrm{Ta}$, deep troughs at $\mathrm{Sr}, \mathrm{P}$ and $\mathrm{Ti}$, and $\mathrm{Ba}$ troughs (except in the Aroeiras granitoids). Aroeiras Complex diorites exhibit peaks in $\mathrm{Ba}$, lowest contents of $\mathrm{K}$, and small troughs in $\mathrm{Th}, \mathrm{U}, \mathrm{Sr}$, and $\mathrm{Ti}$.

The studied granitoids have high HSFE content $(\mathrm{Zr}+$ $\mathrm{Nb}+\mathrm{Ce}+\mathrm{Y}>350 \mathrm{ppm}$ ), plotting in the A-type granites field (Fig. 6A) of Whalen et al. (1987). In the trace-element discrimination diagrams (Pearce et al. 1984), most of the studied samples plot in the within-plate (Fig. 6B) and post-orogenic granites fields with $(\mathrm{Y}+\mathrm{Nb})>50 \mathrm{ppm}$.

\section{Attributes of ferroan intrusions in radioelement distribution maps}

On a regional scale, it is possible to identify several ferroan intrusions already described in the Transversal subprovince (Fig. 7). Due to considerable LILE and HFSE contents, regions mapped as ferroan intrusions exhibit in the radioelements distribution map the highest abundances of these elements compared to their country rocks, or other granitic intrusions.
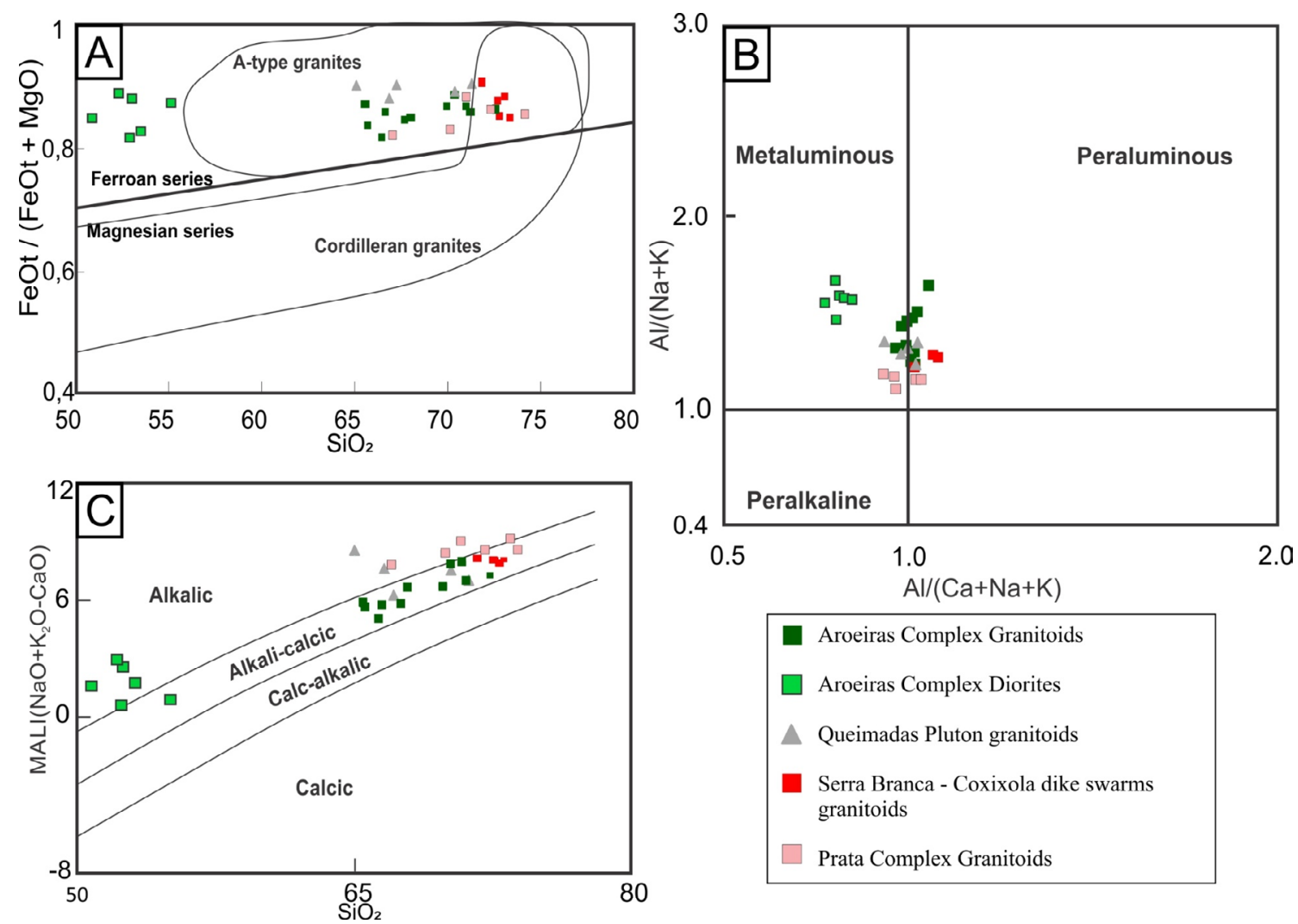

Figure 3. Studied rocks in the (A) FeOt/(FeOt $+\mathrm{MgO})$ versus $\mathrm{SiO} 2$ diagram; (B) Alumina saturation index diagram; (C) Modified alkalilime index versus $\mathrm{SiO} 2$ diagram. 


\section{Aroeiras Complex}

In the ternary radioelements distribution map (Fig. 8A), it is possible to identify three distinct zones within the Aroeiras Complex: the northeastern sector shows high contents of the three elements (K\% > 3\%; eTh, 15-20 ppm; eU, 2-3 ppm), whereas the southwestern and transversal sector show medium
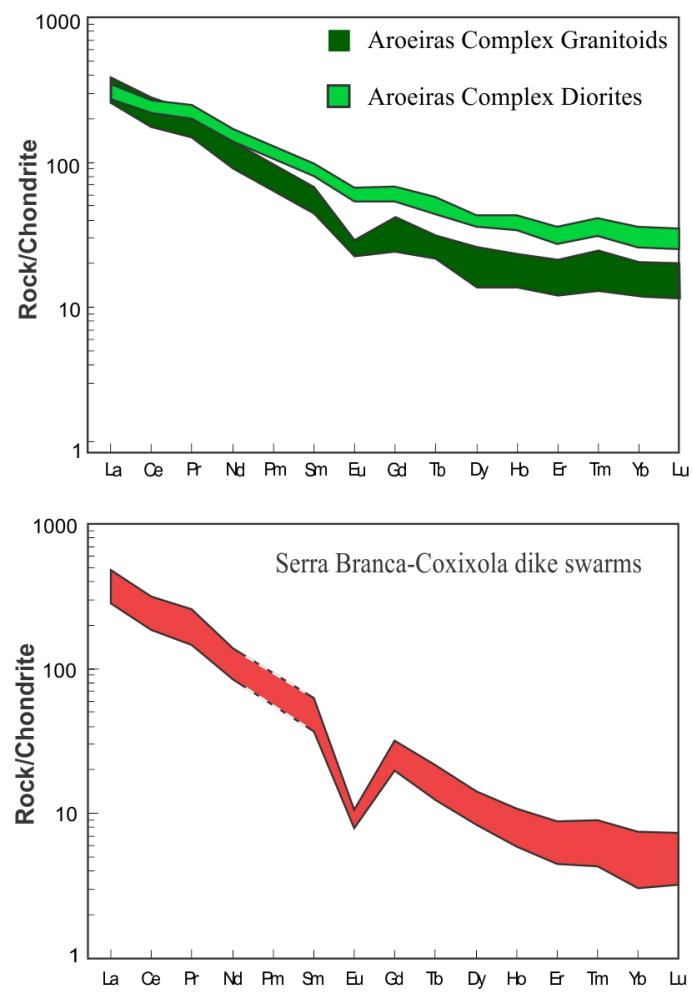

to low values of $\mathrm{K}(1.5-2.13 \%)$ and $\mathrm{eU}(0.5-1.5 \mathrm{ppm})$, and low values of eTh (5-9 ppm) (Figs. 8B, 8C, 8D), and an unclear pattern of elements distribution surrounding those sectors.

In the northeastern zone, leucocratic ferroan alkali-calcic biotite syenogranites are the main lithological facies. They have high modal concentration, up to $1 \%$, of apatite, allanite and
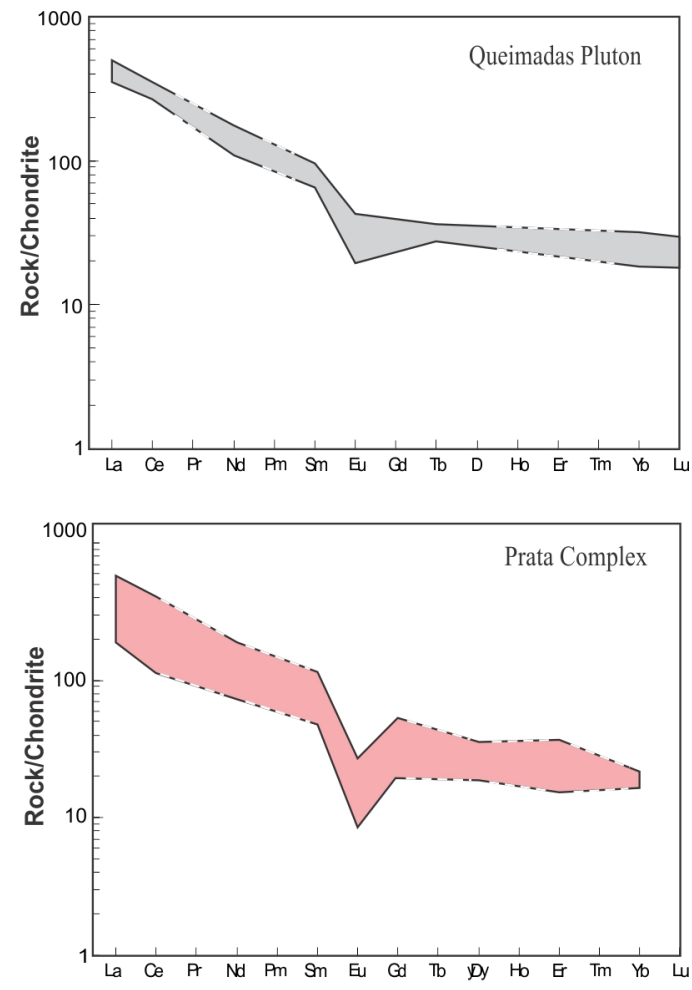

Figure 4. Studied intrusions chondrite-normalized rare earth elements (REE) patterns (Nakamura 1974).
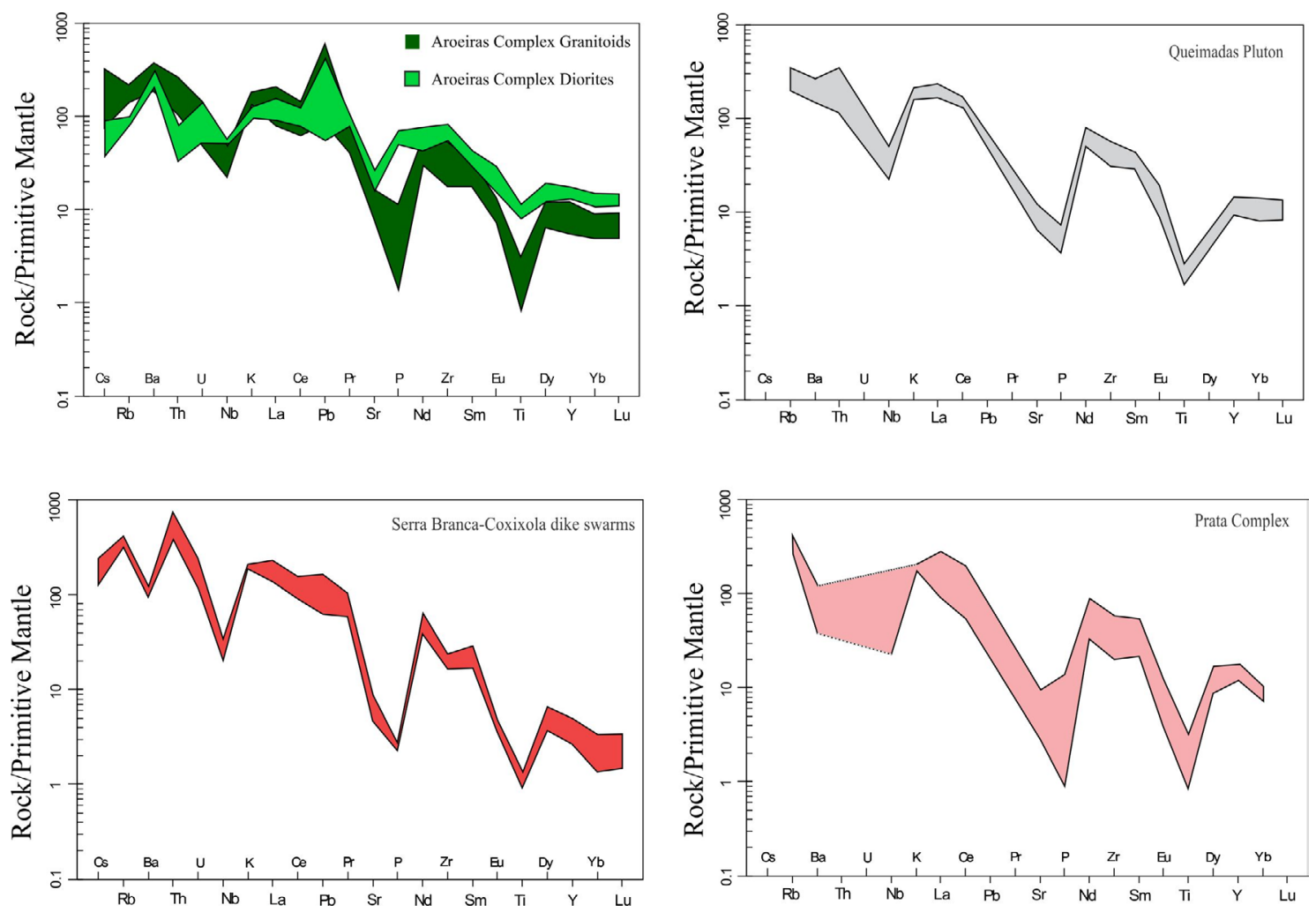

Figure 5. Incompatible trace elements diagram for the studied intrusions normalized to the values suggested by Sun and McDonough (1989). 
zircon, which explain the high values of $U$ and Th, since these minerals are responsible for carrying almost all the contents of these elements in rocks.

The presence of hornblende-biotite diorite bodies marks the southwestern sector of the Aroeiras Complex (Fig. 8).
Despite their alkalic character, $\mathrm{K}_{2} \mathrm{O}$ weight percentages in the diorite bodies are lower (2-3\%) than in the granite (4-5\%), close to those observed in gamma spectrometric maps. The low to intermediate values of $\mathrm{K}$ contrasts with the northwestern sector, which is dominated by biotite syenogranites.
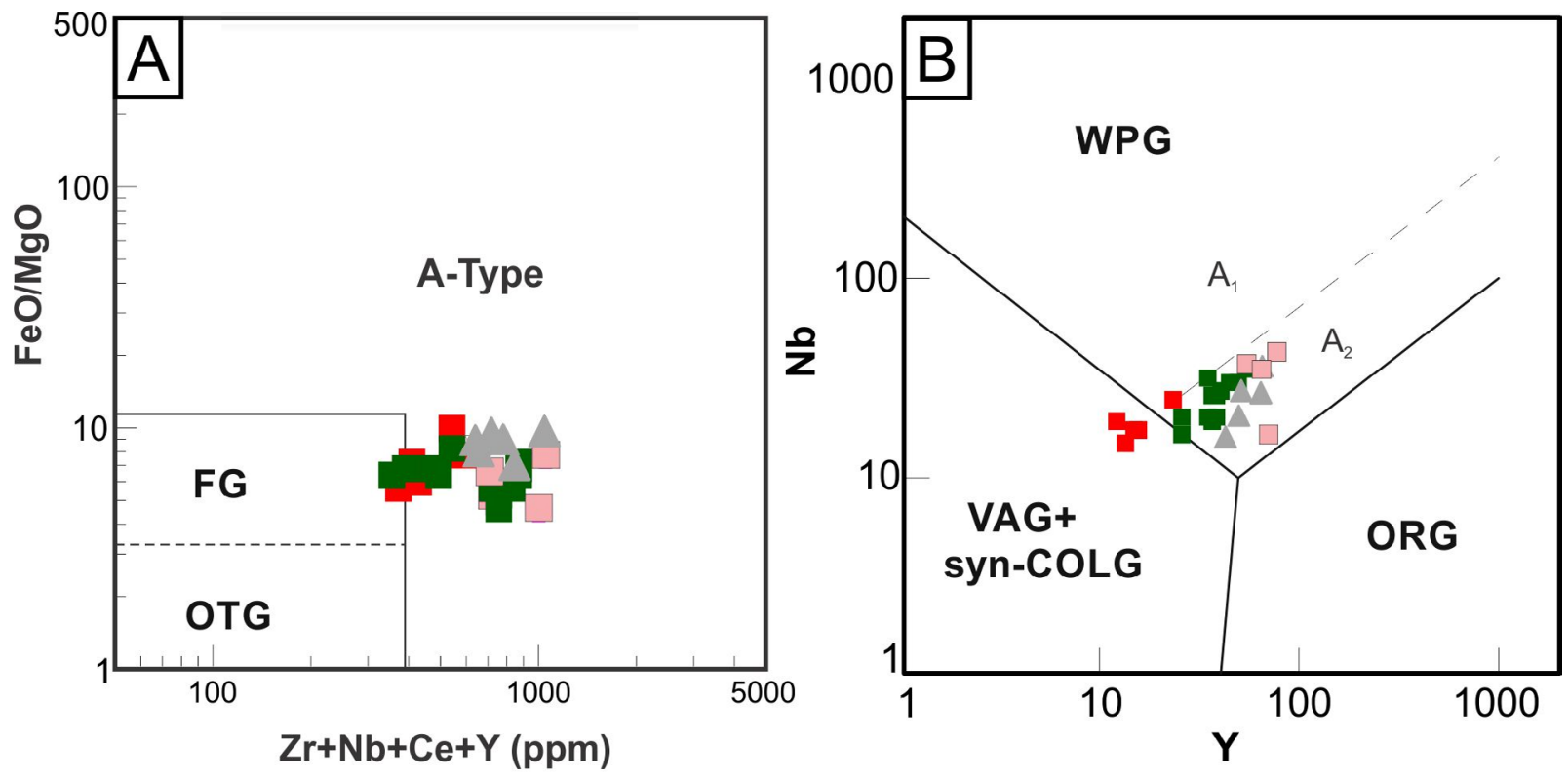

Aroeiras Complex Granitoids $\triangle$ Queimadas Pluton granitoids

Serra Branca - Coxixola dike $\quad \square$ Prata Complex Granitoids swarms granitoids

FG: Fractionated Felsic Granites; OTG: Unfractionated M-, I-, S-type Granites; WPG: Within-Plate Granites; VAG + syn-COLG: Volcanic Arc Granites + syn-Collisional Granites.

Figure 6. Studied ferroan intrusions in tectonic discriminant diagrams. (A) $\mathrm{FeO} / \mathrm{MgO}$ versus $\mathrm{Zr}+\mathrm{Nb}+\mathrm{Ce}+\mathrm{Y}$ (Whalen et al. 1987); (B) Nb versus Y (Pearce et al. 1984).

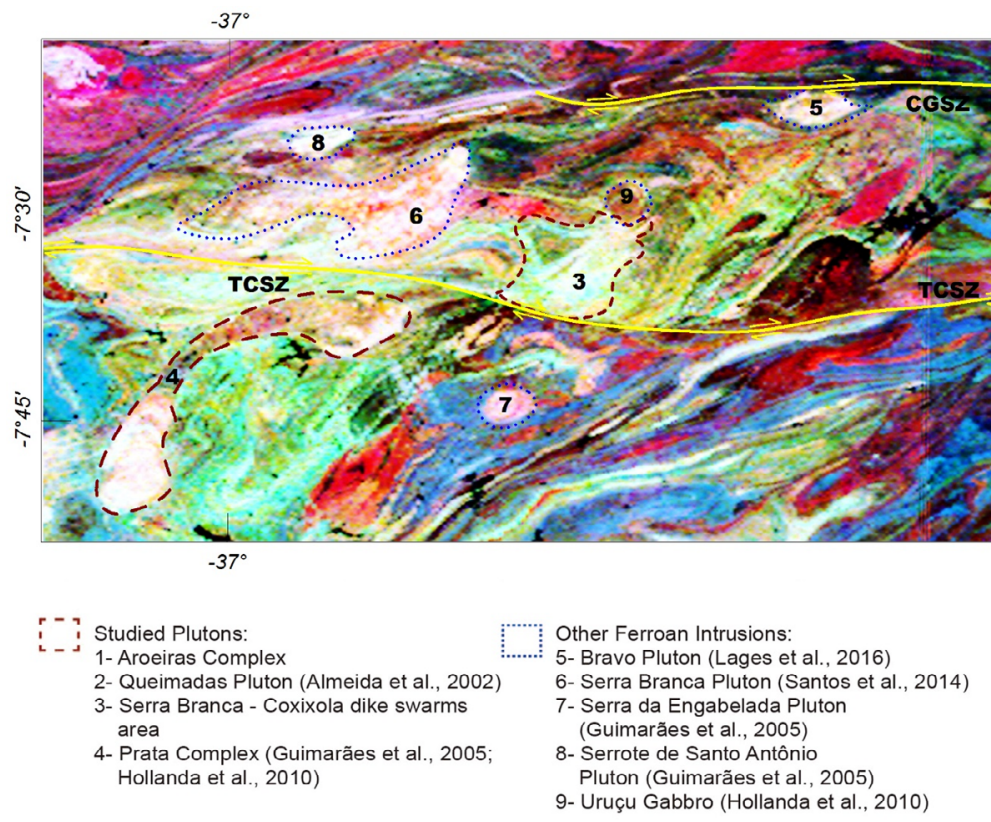

$-36^{\circ}$

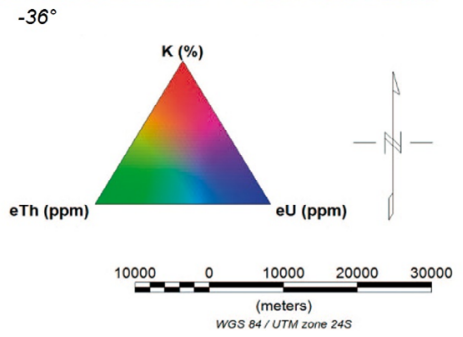

TCSZ: Coxixola shear zone; CGSZ: Campina Grande shear zone; BZS: Batista shear zone.

Figure 7. Radioelements distribution map of the sector within the Transversal subprovince with the studied granitoids and several other ferroan intrusions (Red, Green, Blue (RGB) ternary image). 
Surrounding those sectors, the Aroeiras Complex comprises a heterogeneous rock association, mostly hybrid porphyritic rocks, enclosing dioritic enclaves and leucocratic equigranular biotite granites. Mingling and processes between granitic and dioritic rocks are often chaotic (Flinders and Clemens 1996). Hence, there is an unclear gamma-spectrometric signature related to this process identifiable in this sector of the Aroeiras Complex.

\section{Queimadas Pluton}

The ternary image of the Queimadas Pluton (Fig. 9A) contrasts with the country rocks due to elevated values of $\mathrm{K}$ (values higher than 3\%), eTh (19-30 ppm) and eU (2-3.3 ppm). Nevertheless, eTh and eU concentrations seem higher in the eastern intrusion rather than the western. This signature is evident on the individual counting maps (Figs. 9B, 9C, 9D).

The alkalic to alkali-calcic nature of the granitoids reflect the high $\mathrm{K}$ values of the intrusion. The presence of accessory phase zircon, allanite and monazite (Almeida et al.2002), which are minerals with high contents of radiogenic elements in their structure, explain the high values of eU and eTh observed in the pluton. This mineral assemblage should occur in higher amounts in the west body.

Deformational processes and textures described by Almeida et al. (2002) did not lead to K and U enrichment. Closer to the shear zone disrupting the Queimadas Pluton, values of $\mathrm{K}(\sim 1.8 \%)$ are lower (Fig. 9B). Deformation processes in brittle-ductile conditions, like those described by Almeida et al. (2002), lead to perthite formation and albite replacement in K-feldspar (Pryer and Robin 1995). Consequently, $\mathrm{Na}$ values increase as $\mathrm{K}$ values decrease, explaining lower abundance on $\mathrm{K}$ counts.

\section{Serra Branca: Coxixola dike swarms}

In the SBCDS region, the ternary distribution (Fig. 10A) does not provide much information, apart from high contents of $\mathrm{K}(4.3-5 \%)$, eTh ( $40 \mathrm{ppm})$ and $\mathrm{eU}(>3 \mathrm{ppm})$. Instead, individual channels (Figs. 10B, 10C, 10D) were used
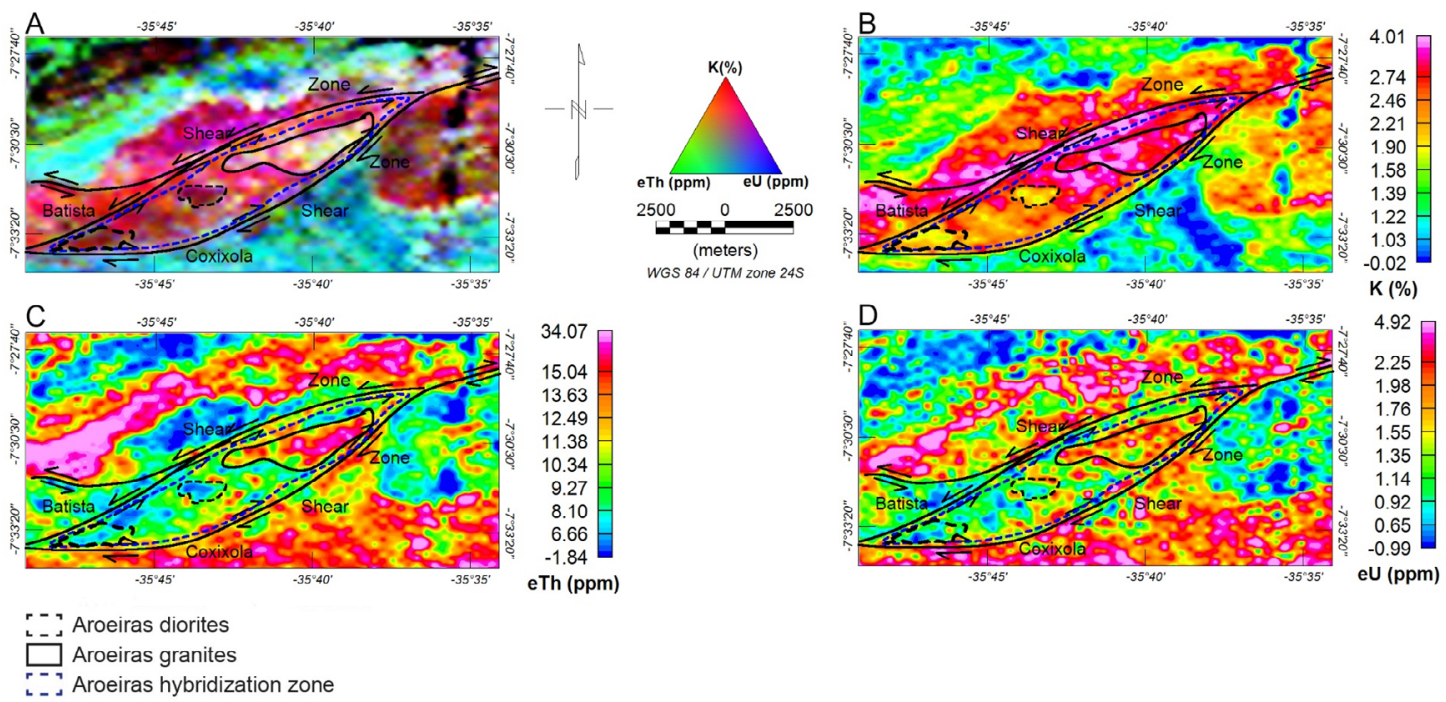

Figure 8. Gamma-ray spectrometric maps of the Aroeiras Complex: (A) ternary composition (RGB); (B) K(\%); (C) eTh (ppm); (D) eU (ppm).
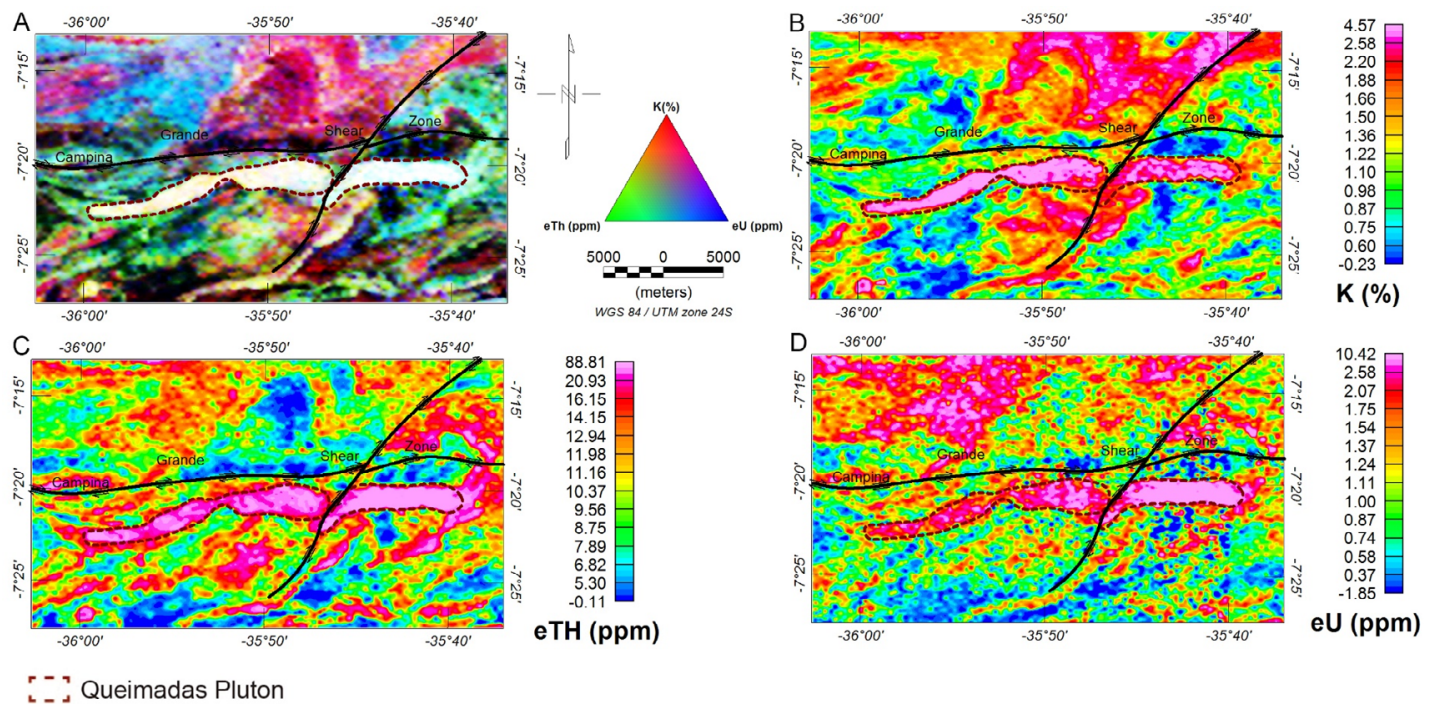

Figure 9. Gamma-ray spectrometric maps of the Queimadas Pluton: (A) ternary composition (RGB); (B) K(\%); (C) eTh (ppm); (D) eU (ppm). 
to trace the main dike population, since they are too small for the flight line spacing (Tab. 2). In these maps, positive contrasts with NE-SW trends in the $\mathrm{K}$ and eU concentrations often coincide with outcrops of dike swarms (black dots in Fig. 10). It is not possible to make any further connections with magmatic processes occurring in these dikes due to their outcrop scale.

Although the Uruçu gabbro (Hollanda et al. 2010) (Figs. 7 and 10) is coeval with the SBCDS, its composition differs distinctively from the ferroan granitoids. Mafic rocks usually display

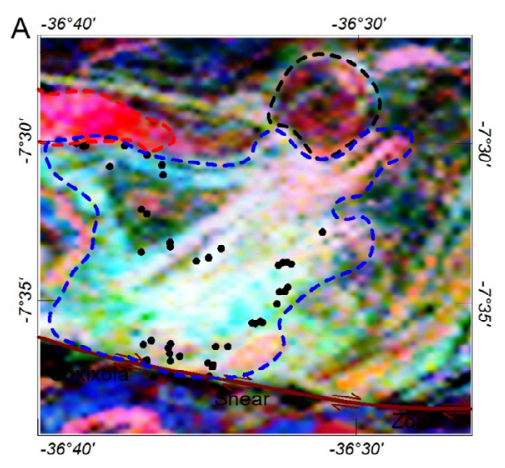

C $-36^{\circ} 40^{\prime}$

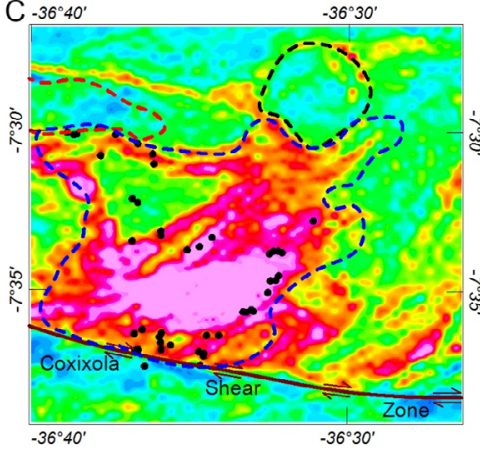

Area of Occurrence of the SBCDS

r- Uruçu Gabbro

Coxixola Pluton
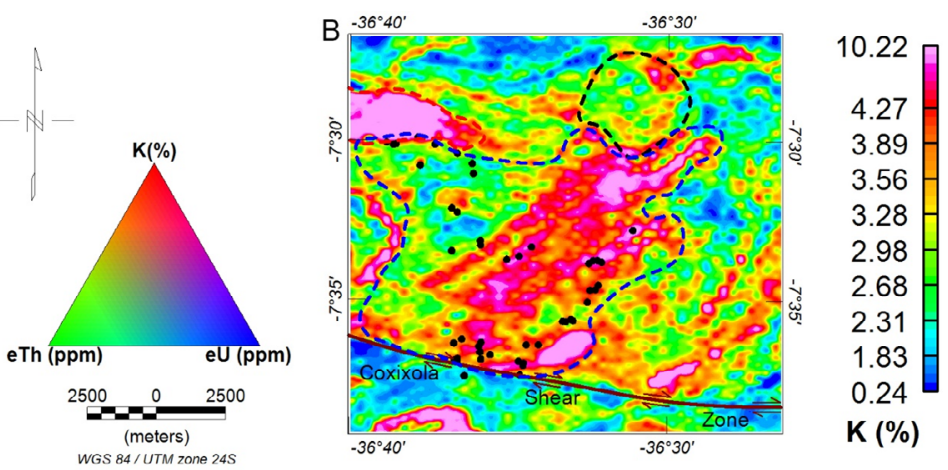

D $-36^{\circ} 40^{\circ}$

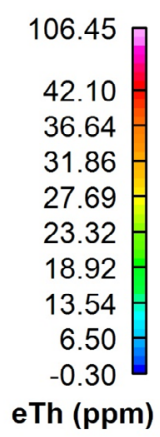

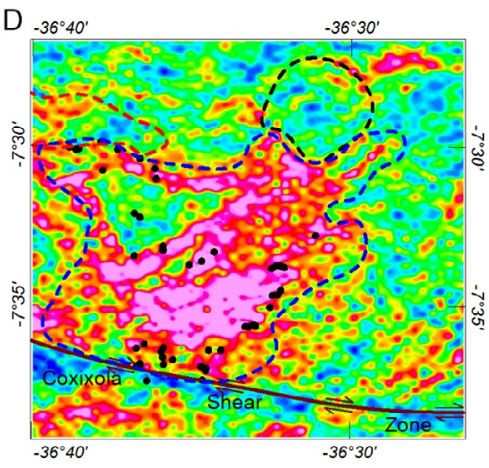

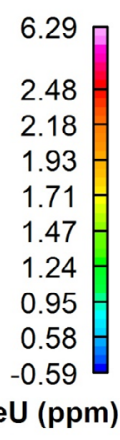

Figure 10. Gamma-ray spectrometric maps of the Serra Branca-Coxixola Dike Swarms (SBCDS) area: (A) ternary composition (RGB); (B) $\mathrm{K}(\%)$; (C) eTh (ppm); (D) eU (ppm). Black dots indicate SBCDS outcrops.
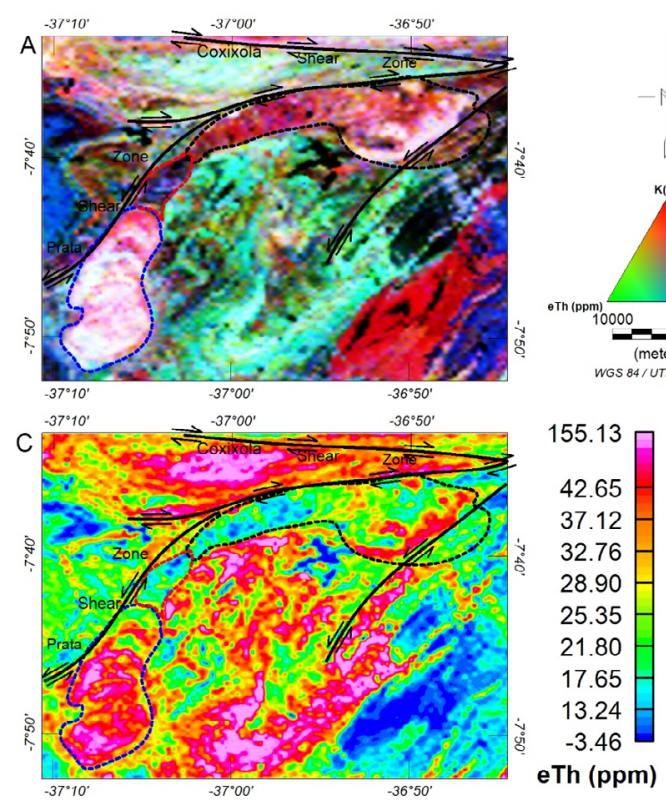
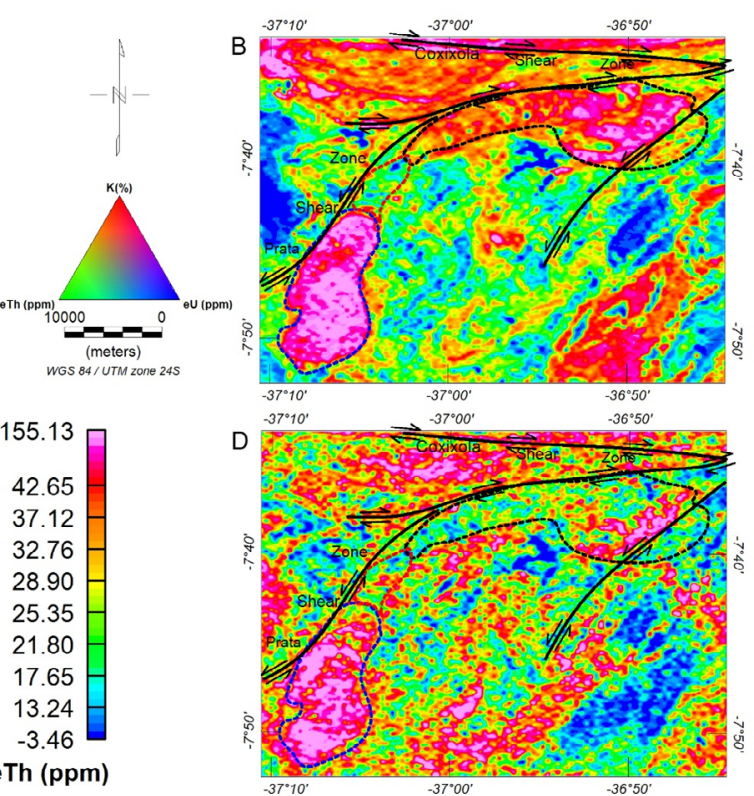

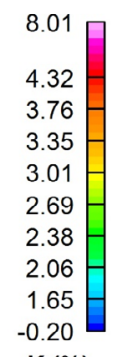

K $(\%)$

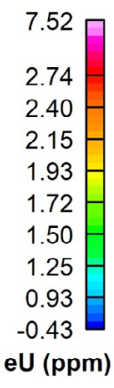

I. - B. Biotite granite

r $\mathrm{L}$ - J H Hornblende-biotite granite

I. G Gabbro Norite

Figure 11. Gamma-ray spectrometric maps of the Prata Complex: (A) ternary composition (RGB); (B) K(\%); (C) eTh (ppm); (D) eU (ppm). 
minor contents of $\mathrm{K}$, Th, and $\mathrm{U}$ in radioelements distribution maps. Hence, gamma spectrometric signature presents low to medium values of eTh (8-20 ppm) and eU (0.2-1.2 ppm), as well as medium values of $\mathrm{K}(2.3-3 \%)$. Medium values of $\mathrm{K}$ are either related to assimilation and magma mixing processes with granitoids of the SBCDS, or the K-enriched nature of the lithospheric mantle beneath the Borborema Province, whichleads to the generation of K-rich mafic to intermediate rocks (Silva Filho et al. 1993, Ferreira et al. 1997, Neves and Mariano, 1997, 2004, Neves et al. 2000, Mariano et al. 2001, Hollanda et al. 2003, Guimarães et al. 2005). However, magma mixing processes between gabbro and leucogranites, as described by Silva et al. (2016), should explain the medium K contents of Uruçu gabbros.

In the triangular area (NW sector of the SBCDS), there are only a few dike outcrops. In this region, orthogneisses with higher mafic contents are abundant. Similar patterns are recognizable in the areas surrounding regions with high occurrence of dike swarms. Accordingly, a lower concentration of radioelements is observed.

\section{Prata Complex}

In the ternary map of radioelements distribution, it is possible to identify the three distinct domains (Fig. 11) comparable with the ones described by Guimarães et al. (2005). The southern pluton exhibits high contents of $\mathrm{K}(\sim 6 \%)$, eTh (27-60 ppm) and eU (2-4 ppm), which is related to mineral abundances with high percentages of microcline $(\sim 50 \%)$, biotite (10\%) and allanite (1.5\%) (Melo 1997). Low contents of $\mathrm{K}(1-2 \%)$ and eTh (9-20 ppm) and low to medium counts of eU (1-2 ppm) dominate its Transversal sector. Guimarães et al. (2005) described this region as mafic rocks of comprising norites with depleted in incompatible elements signatures, probably related to the rise of the asthenospheric mantle in an extensional setting. The north pluton is heterogeneous and characterized by medium to high values of $\mathrm{K}(3-5 \%)$ and variable contents of eU (0.5-4 ppm) and eTh (10-46 ppm). The western part of this pluton has medium contents of $\mathrm{K}$ and $\mathrm{eU}$, and low contents of $\mathrm{eTh}$, as the eastern portion has a region of high contents of the $\mathrm{K}$, eTh, and eU. The north pluton comprises hornblende-biotite-granites, minor amounts of biotite $(\sim 6 \%)$ and allanite $(0.5 \%)$. We suggest that minor radioelements concentration in this granitic intrusion is related to its mineralogical composition, and the widespread presence of dioritic enclave swarms.

\section{CONCLUSIONS}

This study shows that, compared to magnesian granitoids and country rocks, ferroan granitoids radioelements distribution reflect the general characteristics of this cohesive geochemical group of intrusions, as LIL and HFS elements enriched nature, showing higher abundances of $\mathrm{K}$, eTh and eU.

Individually, and in detail, radioelements distribution reflects geochemical changes in response to geological processes (e.g., mineralogical composition, mingling, assimilation, hybridization) syn to post granite emplacement, resulting in remarkably heterogenous intrusions.

For instance, in the Queimadas Pluton, a NE-SW dextral sense shear zone disrupts the granitic body and shear in brittle-ductile conditions are associated with $\mathrm{K}$ decrease in contact with this intrusion.

Geochemical analyses and gamma-ray spectrometric maps exhibit good correspondence, as concentration intervals overlap. Chemical differences between granites, diorites, and gabbros are compatible with those observed in the radioelements distribution maps. For instance, diorites and gabbros have lower contents of $\mathrm{K}_{2} \mathrm{O}(2-3 \%)$, Th (1-7 ppm) and $\mathrm{U}(0.5-3 \mathrm{ppm})$, than the ferroan granites $\mathrm{K}_{2} \mathrm{O}(4.2-6.4) \%$, Th $(16-40 \mathrm{ppm})$ and $U(2-5 \mathrm{ppm})$, feature also observed in gamma spectrometric maps (Gabbros and Diorites: K, 1-3\%; eTh, 5-20 ppm; eU, 0.2-2 ppm; Granites: K, 3-6\%; eTh, 15-60 ppm; eU, 2-4 ppm). Similar behavior is possible to observe in the normalized patterns of incompatible elements.

\section{ACKNOWLEDGEMENTS}

We are grateful for the Brazilian Geological Survey (CPRM) for allowing us to use and publish geophysical data from the projects "Borda Leste do Planalto da Borborema" and "PernambucoParaíba airborne geophysical" surveys. We want to thank the Editor-in-Chief, the Associate Editor, and anonymous reviewers for their constructive criticism, and suggestions to improve the quality of the text. Furthermore, the corresponding author is exceptionally thankful for the support given and wisdom shared by Edilton José dos Santos and during the six-months of internship at CPRM in the year of 2015. This work was supported by Fundação de Amparo à Ciência e Tecnologia do Estado de Pernambuco (FACEPE); under grant [IBPG1074-1.07/15]; and Conselho Nacional de Desenvolvimento Científico e Tecnológico [470255/2013-7-CNPq].

\section{ARTICLE INFORMATION}

Manuscript ID: 20190080. Received on: 08/30/2019. Approved on: 03/19/2020.

V.B.R. was responsible for supervision, improvement and comprehensive reviews regarding the gamma spectrometric signature of the studied intrusions; most of her work was focused into improving the Introduction, Geophysical Data, Attributes of ferroan intrusions in radioelement distribution maps, and conclusions. With J.V.A.A., she helped to prepare, interpret and review Figures 8 to 10. I.P.G. was responsible for supervision, improvement and comprehensive reviews regarding the geological setting and geochemistry of the studied intrusions, focused mainly into improving the Introduction, the Geological setting of the Queimadas Pluton and Prata Complex, the Geochemistry of the Ferroan Intrusions and the Conclusions. Furthermore, she provided the original file of Figure 1 for adaptation in this paper. DJSF has participated in every field season and sample collection for this paper. Thus, he carefully reviewed the geological setting of the intrusions. Additionally, he helped with the development of Figure 2. J.V.L. compiled the geochemical data of the Prata and Queimadas intrusions, participated in the field season to the Aroeiras Complex. His expertise in geochemistry was essential to the development of the Geochemistry of the Ferroan Intrusions. The author also helped to prepare the Figures 3 and 6. A.F.S.F. was responsible for supervision and improvements regarding the Regional geology and analytical data. His contributions were fundamental to the development of the Regional Geology and Whole-rock geochemistry analytical methods.

Competing interests: The authors declare no competing interests. 


\section{REFERENCES}

Accioly A.C.A. 2000. Geologia, geoquímica e significado tectônico do Complexo Metanortosítico de Passira - Província Borborema - nordeste brasileiro. $\mathrm{PhD}$ Thesis, Universidade de São Paulo, São Paulo, 224 p.

Almeida C.N., Guimarães I.P., Silva Filho A.F. 2002. A-type postcollisional granites in the Borborema Province - NE Brazil: The Queimadas Pluton. Gondwana Research, 5(3):667-681. https://doi.org/10.1016/ S1342-937X (05)70637-7

Almeida F.F.M., Hasui Y., Brito Neves B.B., Fuck R. 1981. Brazilian structural provinces: an introduction. Earth-Science Reviews, 17(1-2):1-29. https://doi.org/10.1016/0012-8252(81)90003-9

Almeida F.F.M., Leonardos Jr. O.H., Valença J. 1967. Review on granitic rocks of Northeast South America. In: Symposium on Northeastern South America Granites, Recife. Proceedings ..., IUGS/UNESCO, p. 41.

Amorim J.V.A., Guimarães I.P., Farias D.J.S., Lima J.V., Santos L., Ribeiro V.B., Brainer C. 2019. Late-Neoproterozoic ferroan granitoids of the Transversal Subprovince, Borborema Province, NE Brazil: Petrogenesis and Geodynamic implications. International Geology Review, 61(14):17451767. https://doi.org/10.1080/00206814.2018.1544936

Baumgartner R., Romer R.L., Moritz R., Sallet R., Chiaradia, M. 2006. Columbite tantalite-bearing granitic pegmatites from the Serido Belt, northeastern Brazil: genetic constraints from $\mathrm{U}-\mathrm{Pb}$ dating and $\mathrm{Pb}$ isotopes. Canadian Mineralogist, 44(1):69-86. https://doi.org/10.2113/ gscanmin.44.1.69

Bea F. 1996. Residence of REE, Y, Th and U in granites and crustal protoliths: implications for the chemistry of crustal melts. Journal of Petrology, 37(3):521-552. https://doi.org/10.1093/petrology/37.3.521

Bonin B. 2007. A-type granites and related rocks: evolution of a concept, problems and prospects. Lithos, 97(1-2):1-29. https://doi.org/10.1016/j. lithos.2006.12.007

Brito Neves B.B., Campos Neto M.C., Van Schmus W.R., Santos E.J. 2001. O "Sistema Pajeú-Paraíba" e o "Maciço" Sao José do Campestre no leste da Borborema. Revista Brasileira de Geociências, 31(2):173-184.

Brito Neves B.B., Passarelli C.R., Basei M.A.S., Santos E.J. 2003. Idades $\mathrm{U}-\mathrm{Pb}$ em zircão de alguns granitos clássicos da Província Borborema. Geologia USP, Série Científica, 3:25-38. https://doi.org/10.5327/ S1519-874X2003000100003

Brito Neves B.B., Van Schmus W.R., Santos E.J., Campos Neto M.C., Kozuch M. 1995. O evento Cariris Velhos na Província Borborema: integração de dados, implicações e perspectivas. Revista Brasileira de Geociências, 25(4):279-296.

Companhia de Pesquisa de Recursos Minerais (CPRM). 2008. Projeto Aerogeofísico Borda Leste do Planalto da Borborema. Consórcio LASA Engenharia e Prospecções S.A./PROSPECTORS Aerolevantamentos e Sistemas Ltda. CPRM.

Companhia de Pesquisa de Recursos Minerais (CPRM). 2010. Projeto Aerogeofísico Pernambuco - Paraíba - Riogrande do Norte. Consórcio LASA Engenharia e Prospecções S.A./PROSPECTORS Aerolevantamentos e Sistemas Ltda. CPRM.

Dalan C.A., Vilalva F.C.J., Nascimento M.A.L. 2019. Revaluation of the crystallization conditions of Ediacaran granites in the Rio Piranhas-Serido and Sao Jose do Campestre Domains, Borborema Province, NE Brazil. Geologia USP, Série Cientifica, 19(1):129-152. https://doi.org/10.11606/ issn.2316-9095.v19-149112

Eby G.N. 1992. Chemical subdivision of the A-type granitoids: petrogenetic and tectonic implications. Geology, 20(7):641-644. https://doi. org/10.1130/0091-7613(1992)020\%3C0641:CSOTAT\%3E2.3.CO;2

Ferreira V.P., Sial A.N., Long L.E., Pin C. 1997. Isotopic signatures of Neoproterozoic to Cambrian ultrapotassic syenitic magmas, northeastern Brazil: implications for enriched mantle source. International Geology Review, 39(7):660-669.

Flinders J., Clemens J.D. 1996. Non-linear dynamics, chaos, complexity and enclaves in granitoid magmas. Earth and Environmental Science Transactions of the Royal Society of Edinburgh, 87(1-2):217-223. https://doi. org/10.1017/S0263593300006623
Frost C.D., Frost B.R. 2011. On Ferroan (A-type) Granitoids: their Compositional Variability and Modes of Origin. Journal of Petrology, 52(1):39-53. https://doi.org/10.1093/petrology/egq070

Guimarães I.P., Brito M.F.L., Lages G.A., Silva Filho A.F., Santos L., Brasilino R.G. 2016. Tonian granitic magmatism of the Borborema Province: A review. Journal of South American Earth Sciences, 68:97-112. https://doi. org/10.1016/j.jsames.2015.10.009

Guimarães I.P., Silva Filho A.F., Almeida C.N., Macambira M., Armstrong R.A. 2011. U-Pb SHRIMP data constraints on calc-alkaline granitoids with 1.3-1.6 Ga Nd TDM model ages from the central domain of the Borborema province, NE Brazil. Journal of South American Earth Sciences, 31(4):383-396. https://doi.org/10.1016/j.jsames.2011.03.001

Guimarães I.P., Silva Filho A.F., Almeida C.N., Van Schmus W.R., Araújo J.M.M., Melo S.C., Melo E.B. 2004. Brasiliano (Pan-African) granitic magmatism in the Pajeú-Paraíba belt, Northeast Brazil: an isotopic and geochronological approach. Precambrian Research, 135(1-2):23-53. https://doi.org/10.1016/j.precamres.2004.07.004

Guimarães I.P., Silva Filho A.F., Melo S.C., Macambira M.B. 2005. Petrogenesis of A-type granitoids from Alto Moxotó and Alto Pajeú terranes of the Borborema Province, NE Brazil: constraints from geochemistry and isotopic compositions. Gondwana Research, 8(3):347-362. https://doi. org/10.1016/S1342-937X(05)71140-0

Guimarães I.P., Van Schmus W.R., Brito Neves B.B., Bittar S.M., Silva Filho A.F., Armstrong R. 2012. U-Pb zircon ages of orthogneisses and supracrustal rocks of the Cariris Velhos belt: onset of Neoproterozoic rifting in the Borborema Province, NE Brazil. Precambrian Research, 192-195:5277. https://doi.org/10.1016/j.precamres.2011.10.008

Hollanda M.H.B.M., Archanjo C.J., Souza L.C., Armstrong R., Vasconscelos P.M. 2010. Cambrian mafic o felsic magmatism and its connections with transcurrent shear zones of the Borborema Province (NE Brazil): Implications for the late assembly of West Gondwana. Precambrian Research, 178(1-4):1-14. https://doi.org/10.1016/j.precamres.2009.12.004

Hollanda M.H.B.M., Pimentel M.M., Jardim de Sá E.F. 2003. Paleoproterozoic subduction-related metasomatic signatures in the lithospheric mantle beneath NE Brazil: inferences from trace element and $\mathrm{Sr}-\mathrm{Nd}-\mathrm{Pb}$ isotopic compositions of Neoproterozoic high-K igneous rocks. Journal of South American Earth Sciences, 15(8):885-900. https://doi. org/10.1016/S0895-9811(03)00014-2

Hollanda M.H.B.M., Souza Neto J.A., Archanjo C.J., Stein H., Maia A.C.S. 2017. Age of the granitic magmatism and the W-Mo mineralizations in skarns of the Serido belt (NE Brazil) based on zircon U-Pb (SHRIMP) and Re-Os determinations. Journal Of South American Earth Sciences, 79:1-11. https://doi.org/10.1016/j.jsames.2017.07.011

International Atomic Energy Agency (IAEA). 1991. Airborne gamma ray spectrometer surveying. Technical Reports Series no 323. Viena: International Atomic Energy Agency.

Jardim de Sá E.F., Macedo M.H.F., Torres H.H.F., Kawashita K. 1988. Geochronology of metaplutonics and the evolution of supracrustal belts in the Borborema province. In: Latino-Americano Geological Congress, 7., 1988. Extended Abstracts, p. 49-62.

Johan Z., Johan V. 1994. Oxy fluorures de terres rares de la coupole granitique de Cínovec (Zinnwald), Repúblique Tchèque. CR Academie Sciences de Paris, 318:1225-1231.

Johan Z., Johan V. 2005. Accessory minerals of the Cínovec (Zinnwald) granite cupola, Czech Republic: indicators of petrogenetic evolution. Mineralogy and Petrology, 83:113-150. https://doi.org/10.1007/ s00710-004-0058-0

Kozuch M. 2003. Isotopic and Trace Element Geochemistry of Early Gneissic and Metavolcanic Rocks in the Cariris Velhos Orogen of the Borborema Province, Province, Brazil and Their Bearing Tectonic Setting. PhD thesis, Kansas University, Kansas, $199 \mathrm{p}$.

Lages G.A., Marinho M.S., Nascimento M.A.L., Medeiros V.C., Dantas E.L. 2016. Geocronologia e aspectos estruturais e petrologicos do Pluton Bravo, Domínio Transversal da Província Borborema, Nordeste do Brasil: um granito transalcalino precoce no estágio pos-colisional da Orogenese Brasiliana. Brazilian Journal of Geology, 46(1):41-61. https://doi. org/10.1590/2317-4889201620150033 
Loiselle M.C., Wones D.S. 1979. Characteristics and origin of anorogenic granites. Geological Society of America. Abstracts with Programs, 11:468.

Mariano G., Neves S.P., Silva Filho A.F., Guimarães I.P. 2001. Diorites of the high-K calc-alkalic Association: geochemistry and Sm-Nd data and Implications for the evolution of the Borborema Province, Northeast Brazil. International Geology Review, 43(10):921-929. https://doi. org/10.1080/00206810109465056

Melo S.C. 1997. Petrologia e geoquímica dos granitóides do Complexo Prata a nordeste de Monteiro-PB. Dissertation, Universidade Federal de Pernambuco, Recife, 88 p.

Nakamura N. 1974. Determination of REE, Ba, Fe, Mg, Na, and $\mathrm{K}$ in carbonaceous and ordinary chondrites. Geochimica Cosmochimica Acta, 38(5):757-775. https://doi.org/10.1016/0016-7037(74)90149-5

Neves S.P. 2015. Constraints from zircon geochronology on the tectonic evolution of the Borborema Province (NE Brazil): widespread intracontinental Neoproterozoic reworking of a Paleoproterozoic accreationary orogeny. Journal of South America Earth Science, 58:150-164. https://doi.org/10.1016/j.jsames.2014.08.004

Neves S.P., Bruguier O., Vauchez A., Bosch D., Silva J.M.R., Mariano G. 2006. Timing of crust formation, deposition of supracrustal sequences, and Transamazonian and Brasiliano metamorphism in the East Pernambuco belt (Borborema Province, NE Brazil): implications for western Gondwana assembly. Precambrian Research, 149(3-4):197-216. https://doi. org/10.1016/j.precamres.2006.06.005

Neves S.P., Lages G.A., Brasilino R.G., Miranda A.W.A. 2015. Paleoproterozoic accretionary and collisional processes and the build-up of the Borborema Province (NE Brazil): Geochronological and geochemical evidence from the Transversal Domain. Journal of South America Earth Science, 58:165-187. https://doi.org/10.1016/j.jsames.2014.06.009

Neves S.P., Mariano G. 1997. High-K calc-alkalic plutons in Northeast Brazil: origin of the biotite diorite/quartz monzonite to granite association and implications for the evolution of the Borborema Province. International Geology Review, 39(7):621-638. https://doi.org/10.1080/00206819709465292

Neves S.P., Mariano G. 2004. Heat-producing elements-enriched continental mantle lithosphere and Proterozoic intracontinental orogens: insights from Brasiliano/PanAfrican Belts. Gondwana Research, 7(2):427436. https://doi.org/10.1016/S1342-937X(05)70794-2

Neves S.P., Vauchez A., Archanjo C.J. 1996. Shear zone-controlled magma emplacement or magma-assisted nucleation of shear zones? Insights from northeast Brazil. Tectonophysics, 262(1-4):349-364. https://doi. org/10.1016/0040-1951(96)00007-8

Neves S.P., Vauchez A., Feraud G. 2000. Tectono-thermal evolution, magma emplacement, and shear zone development in the Caruaru area (Borborema Province, NE Brazil). Precambrian Research, 99(1-2):1-32. https://doi. org/10.1016/S0301-9268(99)00026-1

Ostrovsky E.A. 1975. Antagonism of radioactive elements in wallrock alteration fields and its use in aerogamma spectrometric prospescting. International Geology Review, 17(4):461-468. https://doi. org/10.1080/00206817509471687

Pagel M. 1982. The mineralogy and geochemistry of uranium, thorium, and rare-earth elements in two radioactive granits in the Vosges, France. Mineralogical Magazine, 46(339):149-161. https://doi.org/10.1180/ minmag.1982.046.339.01

Pearce J., Harris N.B.W., Tindle A.D. 1984. Trace element discrimination diagrams for the tectonic interpretation of granitic rocks. Journal of Petrology, 25(4):956-983. https://doi.org/10.1093/petrology/25.4.956

Pryer L.L., Robin P.Y.F. 1995. Retrograde metamorphic reactions in deforming granites and the origin of flame perthite. Journal of Metamorphic Geology, 13(6):645-658. https://doi.org/10.1111/j.1525-1314.1995.tb00249.x

Ribeiro V.B., Mantovani M.S.M. 2016. Gamma Spectrometric and Magnetic Interpretation of Cabaçal Copper Deposit in Mato Grosso (Brazil): Implications for hydrothermal fluids remobilization. Journal of Applied Geophysics, 135:223-231. https://doi.org/10.1016/j.jappgeo.2016.10.016

Ribeiro V.B., Mantovani M.S.M., Louro V.H.A. 2014. Aerogamaespectrometria e suas aplicações no mapeamento geológico. Terrae Didática, 10(1):29-51.
Sá J.M., Bertrand J.M., Leterrier J., Macedo M.H.F. 2002. Geochemistry and geochronology of pre-Brasiliano rocks from the TransversalZone, Borborema Province, Northeast Brazil. Journal of South American Earth Sciences, 14(8):851-866. https://doi.org/10.1016/S0895-9811(01)00081-5

Santos E.J. 1995. O complexo granítico Lagoa das Pedras: Acresção e colisão na região de Floresta (Pernambuco) Província da Borborema. PhD Thesis, Universidade de São Paulo, São Paulo, 220 p.

Santos L., Guimarães I.P., Silva Filho A.F., Farias D.J.S., Lima J.V., Antunes J.V. 2014. Magmatismo Ediacarano extensional na Província Borborema, NE Brasil: Pluton Serra Branca. Comunicações Geológicas, 101:199-203.

Santos L.C.M.L., Dantas E.L., Cawood P.A., Santos E.J., Fuck R.A. 2017. Neoarchean crustal growth and Paleoproterozoic crustal reworking in the Borborema Province, NE Brazil: Insights from geochemical and isotopic data of TTG and metagranitic rocks of the Alto Moxoto Terrane. Journal of South American Earth Sciences, 79:342-363. https://doi.org/10.1016/j. jsames.2017.08.013

Santos L.C.M.L., Dantas E.L., Santos E.J., Santos R.V., Lima H.M. 2015. Early to late Paleoproterozoic magmatism in NE Brazil: the Alto Moxoto Terrane and its tectonic implications for the pre-Western Gondwana assembly. Journal of South American Earth Sciences, 58:188-209. https://doi. org/10.1016/j.jsames.2014.07.006

Sial A.N. 1986. Granite-types of Northeast Brazil: current knowledge. Revista Brasileira de Geociências, 16(1):54-72.

Sial A.N., Ferreira V.P. 2016. Magma associations in Ediacaran granitoids of the Cachoeirinha-Salgueiro and Alto Pajeú terranes, northeastern Brazil: Forty years of studies. Journal of South America Earth Sciences, 68:113-133. https://doi.org/10.1016/j.jsames.2015.10.005

Silva Filho A.F., Guimaraes I.P., Thompson R.N. 1993. Shoshonitic and ultrapotassic Proterozoic suites in the Cachoeirinha -Salgueiro fold Belt, NE Brazil: a transition from collisional to post-collisional magmatism. Precambrian Research, 62(3):323-342. https://doi. org/10.1016/0301-9268(93)90028-Z

Silva T.R., Ferreira V.P., Lima M.M.C., Sial A.N. 2016. Two-stage mantle derived granitic rocks and the onset of the Brasiliano orogeny: Evidence from Sr, Nd, and O isotopes. Lithos, 264:189-200. https://doi.org/10.1016/j. lithos.2016.08.030

Sun S.-S., McDonough W.F. 1989. Chemical and isotopic systematics of oceanic basalts: implications for mantle composition and processes Geological Society, London, Special Publications, 42:313-345. https://doi. org/10.1144/GSL.SP.1989.042.01.19

Ulbrich H.H.G.J., Ulbrich M.N.C., Ferreira F.J.F., Alves L.S., Guimarães G.B., Fruchting A. 2009. Levantamentos Gamaespectrométricos em Granitos Diferenciados. I: Revisão da Metodologia e do Comportamento Geoquímico dos Elementos K, Th e U. Geologia USP: Série Científica, 9(1):33-53. https://doi.org/10.5327/Z1519-874X2009000100003

Van Schmus W.R., Brito Neves B.B., Hackspacher P.C., Babinski M. 1995. $\mathrm{U} / \mathrm{Pb}$ and $\mathrm{Sm} / \mathrm{Nd}$ geochronologic studies of Eastern Borborema Province, northeastern Brazil: initial conclusions. Journal of South American Earth Sciences, 8(3-4):267-288. http://dx.doi. org/10.1016/0895-9811(95)00013-6

Van Schmus W.R., Kozuch M., Brito Neves B.B. 2011. Precambrian history of the Zona Transversal of the Borborema Province, NE Brazil: insights from $\mathrm{Sm} / \mathrm{Nd}$ and $\mathrm{U} / \mathrm{Pb}$ geochronology. Journal of South American Earth Sciences, 31 (2-3):227-252. https://doi.org/10.1016/j.jsames.2011.02.010

Van Schmus W.R., Oliveira E.P., Silva Filho A.F., Toteu S.F., Penaye J., Guimaraes I.P. 2008. Proterozoic links between the Borborema province, NE Brazil, and the Transversal African fold belt. Geol. Soc. Lond. Special Publ., 294(1):69-99. http://dx.doi.org/10.1144/SP294.5

Vauchez A., Neves S.P., Caby R., Corsini M., Egydio-Silva M., Arthaud M.H., Amaro V. 1995. The Borborema shear zone system, NE Brazil Journal of South American Earth Sciences, 8(3-4):247-266. https://doi. org/10.1016/0895-9811(95)00012-5

Whalen J.B., Currie K.L., Chappell B.W. 1987. A-types granites: geochemica characteristics, discrimination and petrogenesis. Contributions Mineralogy Petrology, 95:407-419. https://doi.org/10.1007/BF00402202 